\title{
Review of molten carbonate-based direct carbon fuel cells
}

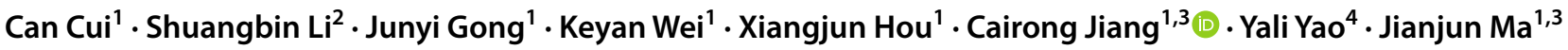

Received: 4 March 2021 / Accepted: 25 June 2021 / Published online: 2 July 2021

(c) The Author(s) 2021

\begin{abstract}
Direct carbon fuel cell (DCFC) is a promising technology with high energy efficiency and abundant fuel. To date, a variety of DCFC configurations have been investigated, with molten hydroxide, molten carbonate or oxides being used as the electrolyte. Recently, there has been particular interest in DCFC with molten carbonate involved. The molten carbonate is either an electrolyte or a catalyst in different cell structures. In this review, we consider carbonate as the clue to discuss the function of carbonate in DCFCs, and start the paper by outlining the developments in terms of molten carbonate (MC)-based DCFC and its electrochemical oxidation processes. Thereafter, the composite electrolyte merging solid carbonate and mixed ionicelectronic conductors (MIEC) are discussed. Hybrid DCFC (HDCFCs ) combining molten carbonate and solid oxide fuel cell (SOFC) are also touched on. The primary function of carbonate (i.e., facilitating ion transfer and expanding the triple-phase boundaries) in these systems, is then discussed in detail. Finally, some issues are identified and a future outlook outlined, including a corrosion attack of cell components, reactions using inorganic salt from fuel ash, and wetting with carbon fuels.
\end{abstract}

Keywords Direct carbon fuel cell $\cdot$ Carbonate $\cdot$ Electrolyte $\cdot$ Catalyst $\cdot$ Triple-phase boundaries (TPBs)

\section{Introduction}

Fuel cells (FCs) offer an environmentally friendly and highly efficient approach to energy-conversion technology for power generation. This approach has been intensively investigated for over a hundred years, since Grove et al. [1] developed the first FC in 1839. This technology is steadily

Can Cui and Shuangbin Li contributed equally to this work.

Cairong Jiang

crjiang@suse.edu.cn

$\triangle$ Jianjun Ma

jjma@suse.edu.cn

1 School of Materials Science and Engineering, Sichuan University of Science and Engineering, Zigong 643000, Sichuan, People's Republic of China

2 School of Chemistry, University of St Andrews, St Andrews KY16 9ST, UK

3 Material Corrosion and Protection Key Laboratory of Sichuan Province, Zigong 643000, Sichuan, People's Republic of China

4 Institute for the Development of Energy for African Sustainability(IDEAS), University of South Africa, cnr Christiaan de Wet and Pioneer Road, Private Bag X6, Florida 1710, South Africa evolving and improving, as the demand for electricity and new electricity generation technologies continues to grow. The FC device generates electric power from gaseous fuels (hydrogen or syngas) by reforming liquefied petroleum gas or liquid fuels. However, the complex synthesis process and the storage and transportation requirements increase the cost. At present, the utilization of carbon fuels is still a preferred option for the development of FCs, due to the abundant resources, easy access and relatively high-energy density. Direct carbon fuel cells (DCFCs), as an energy-conversion technology, generate electricity from solid carbon fuels through electrochemical reactions [2,3]. The device has a higher energy-conversion efficiency rate than traditional power generation devices of heat engines, which minimize system complexity and thus ensure a lower cost [4].

The first DCFC was reported by Becquerel [5] in the middle of the nineteenth century; the configuration was a carbon rod in a $\mathrm{KNO}_{3}$ solution inside a platinum container. In 1896, William Jacques [6] developed a large-scale DCFC using 100 single cells, and baked coal as the anode. The electrolyte was an unspecified mixture of $\mathrm{KOH}$ and/or $\mathrm{NaOH}$ and the cathode was iron pots. Initially, the actual reaction in this system was only deemed to be the chemical reaction of carbon with nitrate [7]. Later research reported that gases from solid carbon pyrolysis are involved in the electrochemical 
reaction $[8,9]$. Other researchers from Stanford Research Institute (SRI, International) investigated this technology thoroughly and invented the actual devices for electricity generation by the electrochemical oxidation of carbon $[10$, 11].

DCFC technology is again receiving interest, especially in terms of the direct carbon oxidation mechanism. Gür [12, 13] proposed that it is appropriate to name the carbon fuel cell a "direct" carbon fuel cell if the reaction is achieved in a single procedure or a single chamber. This proposal is based on the simplified reactions in the anode. However, it is much more complicated in practice. Generally, more than one reaction happens in the anode simultaneously. Among those reactions, carbon is often oxidized into carbon monoxide as an intermediate product, and then $\mathrm{CO}$ is oxidized into $\mathrm{CO}_{2}$ as the final product. We use the term "direct carbon fuel cells" for most carbon fuel cells to be consistent with most publications.

One advantage of DCFC is the emission of pure $\mathrm{CO}_{2}$, unlike other coal-fired power plants, which reduce the technical difficulties of $\mathrm{CO}_{2}$ capture and separation [14]. Notably, the DCFC power station has a modular structure design, which can be adjusted regarding the cost [15]. The direct utilization of various solid carbonaceous materials as fuels is the most distinctive feature of DCFC. Some solid carbon fuels, like graphite, carbon black [16-23] and different types of coal fuel [24-29] have been used in various DCFC configurations.

The carbonaceous materials obtained from renewable resources (e. g., biomass and organic waste) are sustainable fuels due to abundant, cheap and natural characteristics [30]. In recent decades, many researchers have focused on the applications of biochar in the environment and catalysis fields [31-34]. Biomass and municipal waste are also suggested as raw materials to produce clean energy in DCFCs [35-37]. Bio-char is suitable in DCFC for electric energy generation because the biochar obtained by pyrolysis is amorphous, which is conducive to the exposure of carbon fuel surface active sites. Another feature is the high porosity of this kind of biochar, promoting gas transportation in the reaction process [38]. Furthermore, some natural metal ions disperse uniformly in biochar, which are natural catalysts for the carbon gasification reaction [39]. It is worth mentioning that the efficiency of biomass-fueled DCFC is generally $50-60 \%$, while it is up to $80 \%$ if heat and electricity co-generation is applied [40].

There are three types of DCFC; these are categorized according to the electrolyte material, i.e., hydroxide, carbonate and solid oxide. Of these, the molten carbonate direct carbon fuel cell (MC-DCFC) was one of the earliest cells, and it has been widely studied [41]. The molten carbonate also remains stable compared to hydroxide-based cells, even in an environment rich in $\mathrm{CO}_{2}$, which helps to prevent electrolyte damage $[42,43]$. Recently, an investigation was done on hybrid direct carbon fuel cells (HDCFCs), using mixed solid carbon and carbonate in the anode [21]. This overcomes corrosion issues associated with the molten carbonate fuel cell (MCFC) and yields slightly faster kinetics compared to the solid oxide fuel cell (SOFC) system [21].

Some reviews have been done in DCFC, with the earliest reviews of DCFC done by Howard [44] and Liebhafsky [45]. Later, Cao et al. [46, 47] and Giddey et al. [48] summarized the fundamental electrochemical performance and the developments of DCFC technology. The reaction mechanism of direct carbon oxidation and the conversion was explained by Cooper et al. [49] and Gür [13, 50]. Then, Rady et al. [51] reviewed the performance of various fuels used in MCFCs and SOFCs, and Zhou et al. [52] published a review paper that discussed the anode used in DCFCs. Recently, Jiang et al. [53] presented an overview of the impact of different parameters on the resistance and power output and the electrochemical behavior of DCFCs, and also summarized the challenges associated with developing DCFCs. Glenn et al. [54] reviewed the carbon electro-catalysis mechanism of alkali metal molten carbonates in DCFCs.

This paper focuses on providing a broad and timely summary of the carbonate-based DCFC: MC-DCFC, $\mathrm{CO}_{3}{ }^{2-}+$ mixed ionic-electronic conductors (MIEC) and $\mathrm{CO}_{3}{ }^{2-}+$ SOFC. The configurations of three cell systems and some possible reactions related to carbonate are shown in Fig. 1. This review starts with an introduction to molten carbonate species. Then, the fundamental mechanisms of different types of DCFC are provided, with the focus being on the functions of carbonate: (1) transport ions as an electrolyte; (2) catalyze carbon oxidation as a catalyst; (3) enlarge the reaction area, that is, the anode/ electrolyte reaction interface zone. The review concludes with a synopsis of some issues regarding corrosion, compatibility and wettability, and a possible future outlook regarding the utilization of carbonate in DCFC.

\section{Species of molten carbonate in DCFC}

Molten carbonate is commonly used in MCFC, and has received wide attention in DCFC [4, 49]. It shows good compatibility with $\mathrm{CO}_{2}$ when used as an electrolyte [55, 56], and provides excellent ionic conductivity at a relatively low temperature [57]. Furthermore, the molten carbonate in the anode chamber can significantly enlarge triple-phase boundaries (TPBs), which favors ion diffusion to the electrochemical reaction sites [21]. Many studies have shown that doping alkali metal ions in molten carbonate can effectively accelerate the reaction rate of carbon gasification in a $\mathrm{CO}_{2}$ gas stream [58-60]. In particular, potassium salt delivers 


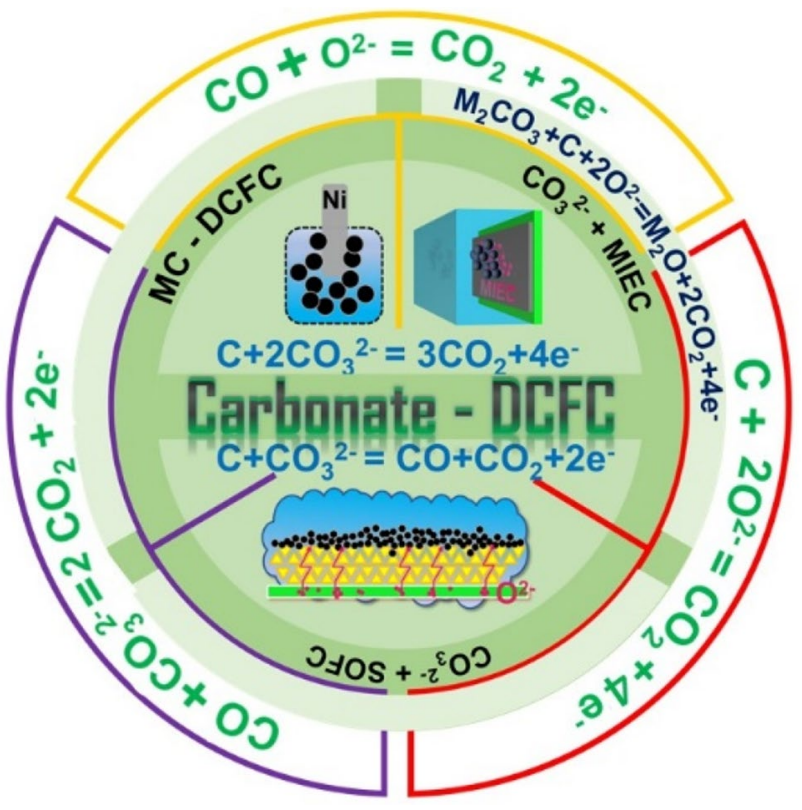

Fig. 1 Schematic of a DCFC in the presence of carbonate, including three cell systems (MC-DCFC, $\mathrm{CO}_{3}{ }^{2-}+\mathrm{MIEC}$ and $\mathrm{CO}_{3}{ }^{2-}+\mathrm{SOFC}$ ) and some possible reactions. The primary reaction between carbonate and carbon is shown in light blue; the electro-catalytic reaction of carbonate with carbon is shown in dark blue; and the possible side reaction is shown in green

high catalytic activity for the carbon gasification reaction [61].

The operating temperature of DCFCs is reduced by changing the carbonate composition while maintaining cell performance, which is another positive factor when using molten carbonate as the electrolyte [62,63]. A suitable amount of other carbonates or oxides can also further reduce the melting temperature of the carbonate [64]. For example, adding an appropriate amount of $\mathrm{Ru}_{2} \mathrm{CO}_{3}$ and $\mathrm{SrCO}_{3}$ to a binary carbonate reduces the surface tension of molten carbonate, which, in turn, increases the solubility of gas and reduces the melting temperature [65]. Therefore, using carbonate with different components in DCFC is discussed in detail.

\section{Binary}

Binary carbonate eutectic has been widely used as an electrolyte material in FCs. It is well known that a lower melting point is obtained with a binary carbonate eutectic $\left(\mathrm{Li}_{2} \mathrm{CO}_{3}-\mathrm{Na}_{2} \mathrm{CO}_{3}, \mathrm{Li}_{2} \mathrm{CO}_{3}-\mathrm{K}_{2} \mathrm{CO}_{3}, \mathrm{~K}_{2} \mathrm{CO}_{3}-\mathrm{Na}_{2} \mathrm{CO}_{3}\right)$ than with a single carbonate $[66,67]$. Of the three binary carbonates, $\mathrm{Li}-\mathrm{K}$ carbonate has the lowest melting point (below $550{ }^{\circ} \mathrm{C}$ ). Therefore, it is more suitable for use as an electrolyte for the cell. However, an early study suggested that a $\mathrm{Li}-\mathrm{Na}$ carbonate eutectic exhibited certain benefits in comparison with a $\mathrm{Li}-\mathrm{K}$ carbonate eutectic, such as a higher
Table 1 Melting point of various carbonates

\begin{tabular}{lll}
\hline Carbonate & $\begin{array}{l}\text { Melting } \\
\text { point }\left({ }^{\circ} \mathrm{C}\right)\end{array}$ & Ref \\
\hline Lithium carbonate & 723 & {$[67]$} \\
Sodium carbonate & 851 & {$[67]$} \\
Potassium carbonate & 891 & {$[67]$} \\
Lithium and sodium carbonate $(52: 48$ in mole) & 501 & {$[66]$} \\
Lithium and potassium carbonate $(62: 38$ in mole) & 492 & {$[66]$} \\
Sodium and potassium carbonate $(56: 44$ in mole) & 720 & {$[66]$} \\
Lithium, sodium and potassium carbonate & 397 & {$[73]$} \\
$\quad(43.5: 31.5: 25$ in mole) & & \\
\hline
\end{tabular}

ionic conductivity (the ionic conductivity of $43.5 \mathrm{~mol} \%$ $\mathrm{Li}_{2} \mathrm{CO}_{3}-31.5 \mathrm{~mol} \% \mathrm{Na}_{2} \mathrm{CO}_{3}-25 \mathrm{~mol} \% \mathrm{~K}_{2} \mathrm{CO}_{3}, 52 \mathrm{~mol} \%$ $\mathrm{Li}_{2} \mathrm{CO}_{3}-48 \mathrm{~mol} \% \mathrm{~K}_{2} \mathrm{CO}_{3}$ and $72 \mathrm{~mol} \% \mathrm{Li}_{2} \mathrm{CO}_{3}-28 \mathrm{~mol} \%$ $\mathrm{Na}_{2} \mathrm{CO}_{3}$ at $600{ }^{\circ} \mathrm{C}$ is $1.20 \mathrm{~S} \mathrm{~cm}^{-1}, 1.15 \mathrm{~S} \mathrm{~cm}^{-1}$, and $1.79 \mathrm{~S}$ $\mathrm{cm}^{-1}$, respectively) [68]. The $\mathrm{Li}-\mathrm{Na}$ carbonate eutectic has a lower dissolution rate of in the cathode $(\mathrm{NiO})$ than that of $\mathrm{Ni}$ generated by $\mathrm{NiO}$ reduction, and it is quickly oxidized to nickel oxide [69].

The cell life of different carbonate components is predicted based on the evaporated carbonate lost. $\mathrm{Li}-\mathrm{Na}$ carbonate has a greater projected lifetime of $10.3 \times 10^{5} \mathrm{~h}$ at $600^{\circ} \mathrm{C}$, compared to the $6.4 \times 10^{5} \mathrm{~h}$ for $\mathrm{Li}-\mathrm{Na}-\mathrm{K}$ carbonate and the $6.3 \times 10^{5} \mathrm{~h}$ for Li-K carbonate [70]. Therefore, $\mathrm{Li}-\mathrm{Na}$ carbonate has often been used as an electrolyte in MCFC to substitute the $\mathrm{Li}-\mathrm{K}$ carbonate. Nevertheless, there may be a risk of a rapid decrease in cell voltage with $\mathrm{Li}-\mathrm{Na}$ carbonate at atmospheric pressure and low temperature $\left(\leq 600^{\circ} \mathrm{C}\right)$ because of the relatively low solubility of oxygen in this eutectic [71]. Na-K carbonate eutectic showed the worst cell performance of the various binary carbonate-based DCFCs, probably due to its high melting temperature [72].

One investigation showed that, when using sawdust biofuel, HDCFC with a Li-K carbonate eutectic as the medium in anode showed excellent cell performance $\left(789 \mathrm{~mW} \mathrm{~cm}^{-2}\right)$ at $750{ }^{\circ} \mathrm{C}$ [46]. The low melting point of $\mathrm{Li}-\mathrm{K}$ carbonate is one of the influencing factors on excellent cell performance because the viscosity of its solution can be reduced when the temperature reaches the melting point, thereby improving the diffusion of solid fuel in the medium. And also, Li-K carbonate is a good catalyst for gasification reactions [22]. Table 1 provides the melting temperatures of the common carbonates.

\section{Ternary}

A ternary carbonate eutectic of lithium, sodium and potassium carbonate as the carbon oxidation medium is a potential choice in DCFCs. Initially, the ternary carbonate eutectic was selected as an electrolyte in DCFC due to its good

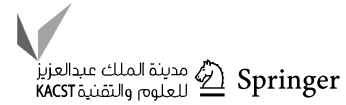


compatibility with unexpected pollutants, such as sulfur and ash contents in coal [10]. Furthermore, compared with the binary carbonate eutectic mixed DCFC, the ternary system $\left(\mathrm{Li}_{2} \mathrm{CO}_{3}-\mathrm{Na}_{2} \mathrm{CO}_{3}-\mathrm{K}_{2} \mathrm{CO}_{3}\right)$ has the lowest melting point [73]. (See Table 1.)

Vutetakis et al. [74] employed a ternary carbonate of $\mathrm{Li}_{2} \mathrm{CO}_{3}-\mathrm{K}_{2} \mathrm{CO}_{3}-\mathrm{Na}_{2} \mathrm{CO}_{3}$ with a weight ratio of 32.1:34.5:33.4 in DCFC with coal as the fuel, and found that it was capable of reducing the cell operating temperature to $500{ }^{\circ} \mathrm{C}$. Jiang et al. [75] also applied a ternary carbonate of $\mathrm{Li}_{2} \mathrm{CO}_{3}, \mathrm{Na}_{2} \mathrm{CO}_{3}$ and $\mathrm{K}_{2} \mathrm{CO}_{3}$ in a mole ratio of 43.5:31.5:25 in coal-fueled HDCFC. The cell generated a maximum power density of $50.02 \mathrm{~mW} \mathrm{~cm} \mathrm{~cm}^{-2}$ with an opencircuit voltage (OCV) of $1.1 \mathrm{~V}$ at $700{ }^{\circ} \mathrm{C}$.

\section{Carbonate in DCFC}

In DCFC, carbonate can contact carbon particles in the electrolyte or anode compartment directly, to catalyze the reaction of carbon oxidation. It can also be used as an electrolyte for ion transportation in MC-DCFC and $\mathrm{CO}_{3}{ }^{2-}+\mathrm{MIEC}$. The difference is that, in the molten state, carbonate has a catalytic effect on carbon oxidation, due to carbonate mixing with carbon particles in the former system, but carbonate combines with MIEC materials is a solid electrolyte form in the latter. By introducing carbonate in the HDCFC anode, cell performance is improved, possibly due to the catalytic effect on carbon oxidation and the enlargement of the reaction interface. Therefore, it is critical to discuss the role of carbonate in DCFC. Table 2 summarizes some configurations used in carbonate-based DCFCs.

\section{MC-DCFC}

MCFC is a commercial fuel cell. Its scale is gradually expanded from kilowatt to megawatt [84]. Besides gaseous fuel, solid carbon is also used as fuel in this cell system. Some progress has been made with developing different cell structures and materials of MC-DCFC, followed by different electrode reaction mechanisms.

\section{Configuration}

Baur et al. [85] replaced all the molten hydroxide electrolytes with molten carbonate electrolytes, which opened up the study of MCFCs. In the 1970s, researchers from SRI International first dispersed a carbon particle in a molten $\mathrm{Pb}$ using a molten alkali metal carbonate as the electrolyte [86, 87]. Following the first trial, the researchers used coal as the anode in an MC-DCFC with $\mathrm{Li}-\mathrm{Na}-\mathrm{K}$ ternary carbonate electrolyte [10]. Some reports claimed that some alkali metal salts (such as $\mathrm{Li}_{2} \mathrm{CO}_{3}$ ) are regarded as a catalytic agent for accelerating carbon gasification [88, 89], which further suggests the possibility of using carbonate in DCFC. Some researchers from Lawrence Livermore National Laboratory in the United States (LLNL, USA) then made significant progress in MC-DCFC, particularly in terms of the materials related to cathode catalysts, aerogels and xerogel carbon anodes [82-94].

The unconventional tilted design was invented by Cooper et al. [95] using molten carbonate (32 mol\% $\mathrm{Li}_{2} \mathrm{CO}_{3}-68 \mathrm{~mol} \% \mathrm{~K}_{2} \mathrm{CO}_{3}$ ) as the electrolyte (See Fig. 2a). The cell cathode is composed of a lithiated $\mathrm{NiO}$, while the anode is made of the carbon-carbonate slurry mixture and the Ni current collector. The key aspect of this device is the electrolyte bed of $\mathrm{ZrO}_{2}$ fabric filled with molten salt that conducts ions while preventing a short circuit of the electrodes. This device presents a $5-45^{\circ}$ inclined angle, which favors a continuous fuel supply and facilitates the discharge of excess electrolyte to prevent the electrolyte from flooding the cathode. The cell surface area was expanded from the conventional $2-60 \mathrm{~cm}^{2}$ with no significant polarization loss [48].

Later, researchers presented another carbon/air molten carbonate cell, as illustrated in Fig. 2b. The composite electrode composed of foam nickel and stainless steel made a great contribution to the stability of the cell structure [41]. This design was called 'planar MC-DCFC' due to the mixture of carbon and carbonate located above the anode where the redox reactions occur. A low cell resistance (the resistance of carbon aerogel and the anode current collector was $0.4 \Omega \mathrm{cm}^{2}$ ) was obtained in this configuration, and therefore improved cell performance.

A schematic of the MC-DCFC prepared by Li et al. [96] is shown in Fig. 2c. The method applied was similar to that used by Vutetakis et al. [74]. This MC-DCFC consists of three electrodes: a working electrode (WE); a gold counter electrode (CE); and a $12 \mathrm{~mm}$ diameter alumina sheath that serves as the reference electrode (RE). An Inconel stirring bar is also introduced into the molten carbonate electrolyte to ensure the uniform distribution of carbon particles and improve mass transfer process inside the cell. However, the power density in this configuration is not good enough because the reaction area (fuel/electrode/electrolyte contact area) is severely limited. In this case, the reaction area is only a few square centimeters in the $250 \mathrm{~g}$ melt carbonate bath [97].

In an effort to extend the formation zone of TPBs, a fluidized bed cell with a three-dimensional (3D) electrode was adopted by Gür and Huggins [100]. Zhang et al. [98, 101] showed another one with a self-designed fluidized bed electrode anode, as shown in Fig. 2d. In this design, the bubbling gas is applied in DCFC to ensure mass and heat transfer.

Recently, a tubular DCFC with a closed-end structure was conceived by Ido et al. [99], using carbonate as the 
(a)

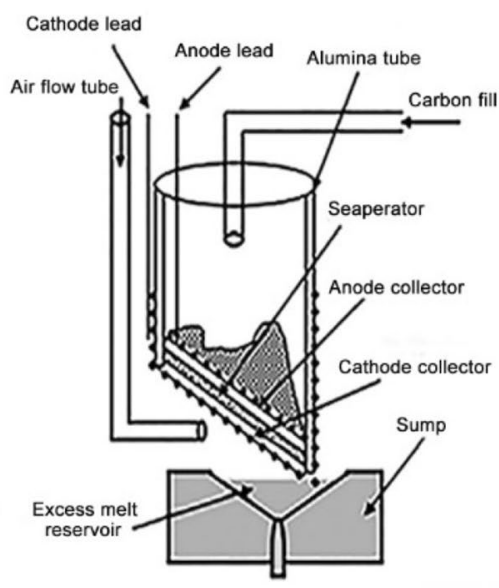

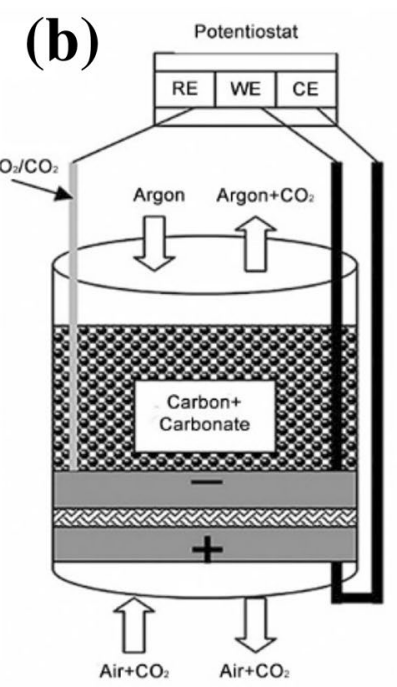

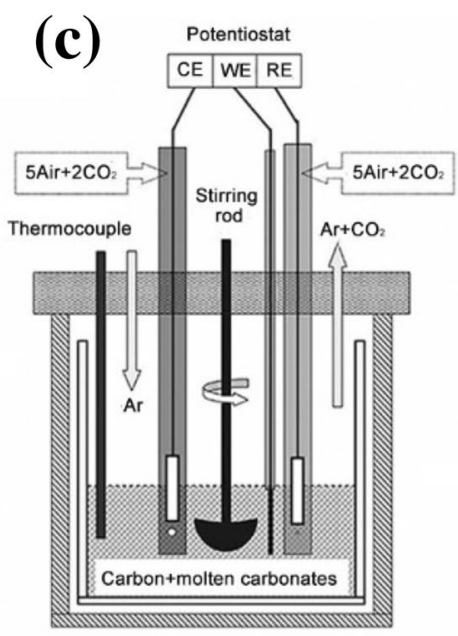

(d)

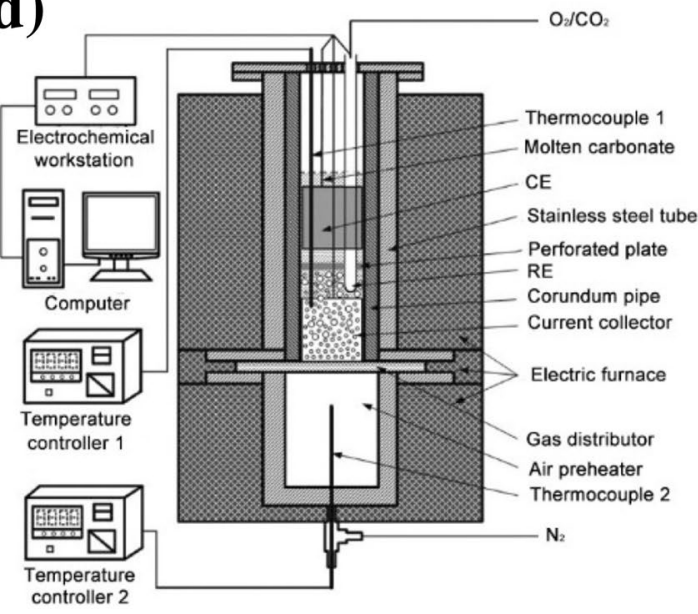

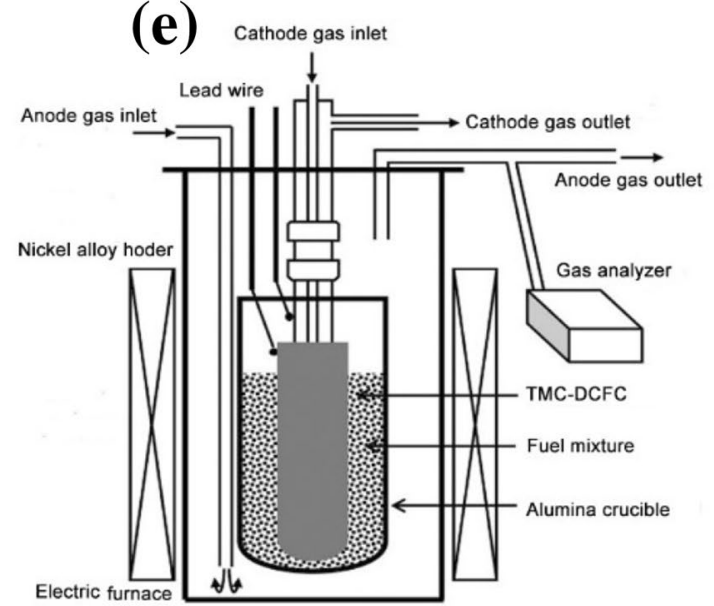

the mass transfer process inside the cell; d FBEDCFC using the bubbling gas to agitate a mixture of carbon and molten carbonate to accelerate mass and heat transfer; e TMC-DCFC with a closed-end structure that ensures there is no short circuit and that there is a continuous solid fuel supply. Reproduced from refs. [41, 95, 96, 98, 99]

carbonate electrolyte to achieve mass balance (as given by Eq. 2). The reactions are detailed below $[102,103]$.

Anode : $\mathrm{C}+2 \mathrm{CO}_{3}^{2-}=3 \mathrm{CO}_{2}+4 \mathrm{e}^{-}$

Cathode: $\mathrm{O}_{2}+2 \mathrm{CO}_{2}+4 \mathrm{e}^{-}=2 \mathrm{CO}_{3}^{2-}$

The total reaction is shown in Eq. (3).

Overall reaction : $\mathrm{C}+\mathrm{O}_{2}=\mathrm{CO}_{2}$

In the MC-DCFC system, the solid carbon fuel can be oxidized directly to $\mathrm{CO}_{2}$ (as given in Eq. 1). Thereafter, it is circulated to the cathode compartment through the molten 
The above equations also indicate that $\mathrm{P}_{\mathrm{CO}_{2}}$ could influence the open-circuit voltage (OCV) of the cell, as shown in Eq. (4) [41].

$\mathrm{E}=\mathrm{E}^{\mathrm{o}}+\mathrm{RT} / 4 \mathrm{~F} \ln \left[\mathrm{P}_{\mathrm{O}_{2}}\right]\left[\mathrm{P}_{\mathrm{CO}_{2}}\right]_{\text {cathode }}^{2} /\left[\mathrm{P}_{\mathrm{CO}_{2}}\right]_{\text {anode }}^{3}$

The possible oxidation reactions of carbon in MC-DCFC and the gas produced are shown in Fig. 3, which shows that: the decomposition of carbonate can also produce $\mathrm{CO}_{2}$; it has an influence on the DCFC performance (Eq. 5) [104]. One investigation showed a noticeable increase in over-potential at a higher current density, owing to the mass transfer process being prevented, but it was easy for the released $\mathrm{CO}_{2}$ gas to make contact with the carbon and ions at the anode again, with a long-term discharge recorded [105].

Generally, it requires a high operating temperature to enhance the anode reaction rate. Early experimental results show that the predominant product with a carbon anode is CO above $700{ }^{\circ} \mathrm{C}$ and this is dependent on the reversal of the Boudouard reaction (as given by Eq. 6). Expected energy from reaction (Eq. 1) is halved, because only two equivalent charges are obtained from one mole of carbon without a significant voltage change at $750{ }^{\circ} \mathrm{C}$.

$\mathrm{CO}_{3}^{2-}=\mathrm{CO}_{2}+\mathrm{O}^{2-}$

$\mathrm{C}+\mathrm{CO}_{2}=2 \mathrm{CO}$

Other reactions besides the Boudouard reaction are possible, such as partial oxidation of carbon, as shown in Eqs. (7) and (8) [106].

$2 \mathrm{C}+\mathrm{CO}_{3}^{2-}=3 \mathrm{CO}+2 \mathrm{e}^{-}$

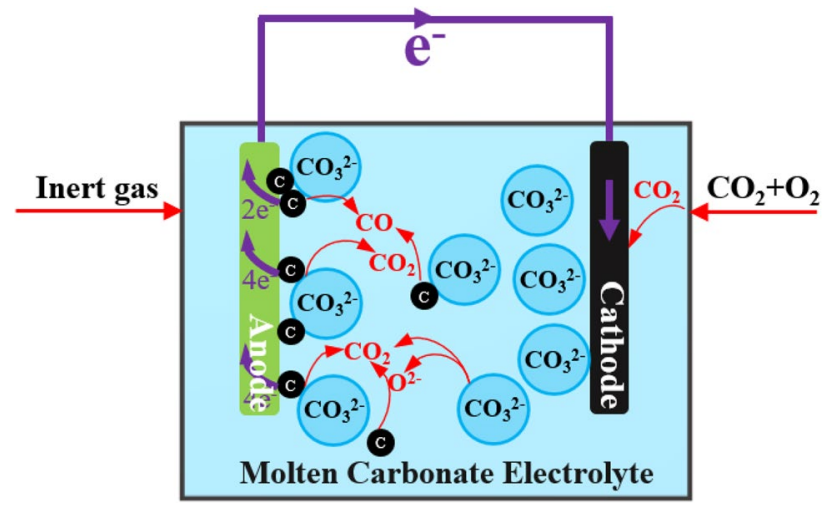

Fig. 3 Schematic of the MC-DCFC system: $\mathrm{CO}_{2}$ and $\mathrm{O}_{2}$ gain electrons to produce carbonate ion at the cathode; carbonate ion and carbon generate $\mathrm{CO}$ or $\mathrm{CO}_{2}$ and electrons at the anode. At the same time, carbonate ion is likely to decompose into $\mathrm{O}^{2-}$ and $\mathrm{CO}_{2}$
$\mathrm{C}+\mathrm{CO}_{3}^{2-}=\mathrm{CO}+\mathrm{CO}_{2}+2 \mathrm{e}^{-}$

The main product of the carbon anode is identified as $\mathrm{CO}_{2}$ through off-gas analysis [107]. The electrochemical formation of CO is not an insurmountable problem in DCFC, as this reaction in the anode compartment occurs only in the process of cell operation [74]. The OCV value can be diminished or even eliminated if pure $\mathrm{CO}_{2}$ is blown into the anode compartment under the cell when operating above $700{ }^{\circ} \mathrm{C}$, or when the $\mathrm{CO}_{2}$ residue in the open-circuit condition is minimal (Table 2).

Cooper et al. [41, 108] proposed that the mechanisms of carbon oxidation in MCFC are the same as in the Hall process, as given by Eqs. (9-14), while MCFC also forms oxygen ions. The oxygen ions are formed by the ready decomposition of the molten carbonate at the DCFC operating temperature (as given by Eq. 5), which triggers the subsequent oxidation reactions of carbon.

$\mathrm{C}_{\mathrm{RS}}+\mathrm{O}^{2-}=\mathrm{C}_{\mathrm{RS}} \mathrm{O}^{2-} \quad$ Fast adsorption on carbon reactive sites

$\mathrm{C}_{\mathrm{RS}} \mathrm{O}^{2-}=\mathrm{C}_{\mathrm{RS}} \mathrm{O}^{-}+\mathrm{e}^{-} \quad$ Fast discharge

$\mathrm{C}_{\mathrm{RS}} \mathrm{O}^{-}=\mathrm{C}_{\mathrm{RS}} \mathrm{O}+\mathrm{e}^{-} \quad$ Fast discharge

$\mathrm{C}_{\mathrm{RS}} \mathrm{O}+\mathrm{O}^{2-}=\mathrm{C}_{\mathrm{RS}} \mathrm{O}_{2}^{2-} \quad$ Slow adsorption:Rate determining step

$\mathrm{C}_{\mathrm{RS}} \mathrm{O}_{2}^{2-}=\mathrm{C}_{\mathrm{RS}} \mathrm{O}_{2}^{-}+\mathrm{e}^{-} \quad$ Fast discharge

$\mathrm{C}_{\mathrm{RS}} \mathrm{O}_{2}^{-}=\mathrm{CO}_{2}(\mathrm{~g})+\mathrm{e}^{-} \quad$ Fast discharge and outgassing

The above reactions indicate that oxidation of carbon monoxide is key to the whole carbon oxidation process, because carbon is easily oxidized to $\mathrm{CO}$ with the one-electron transfer. The combination of carbon and $\mathrm{O}^{2-}$ is affected by the number and concentration of carbon active sites, depending on the carbon surface area. Li et al. [96] used different carbon sources as the fuel and proposed that the redox reaction rate in carbonate slurry is mainly determined by the crystallinity and surface properties, especially the surface area and the quantity of the carbon surface functional group. These results also verify the rationality of Cherepy's electrochemical mechanism to a certain extent.

Recently, more attention has been paid to tailoring the cell structure to improve the performance of MC-DCFC. Lee et al. [109] proposed that the addition of $\mathrm{Gd}_{2} \mathrm{O}_{3}$ to a $\mathrm{Ni}$ anode improved cell performance due to the enlarged TPBs and the reduced charge-transfer resistance. They also concluded that the Ni: $\mathrm{Gd}_{2} \mathrm{O}_{3}=1: 5$ anode was an optimal value between the wettability and the electronic conductivity. Then, Lee et al. [78] also reported that the addition of 


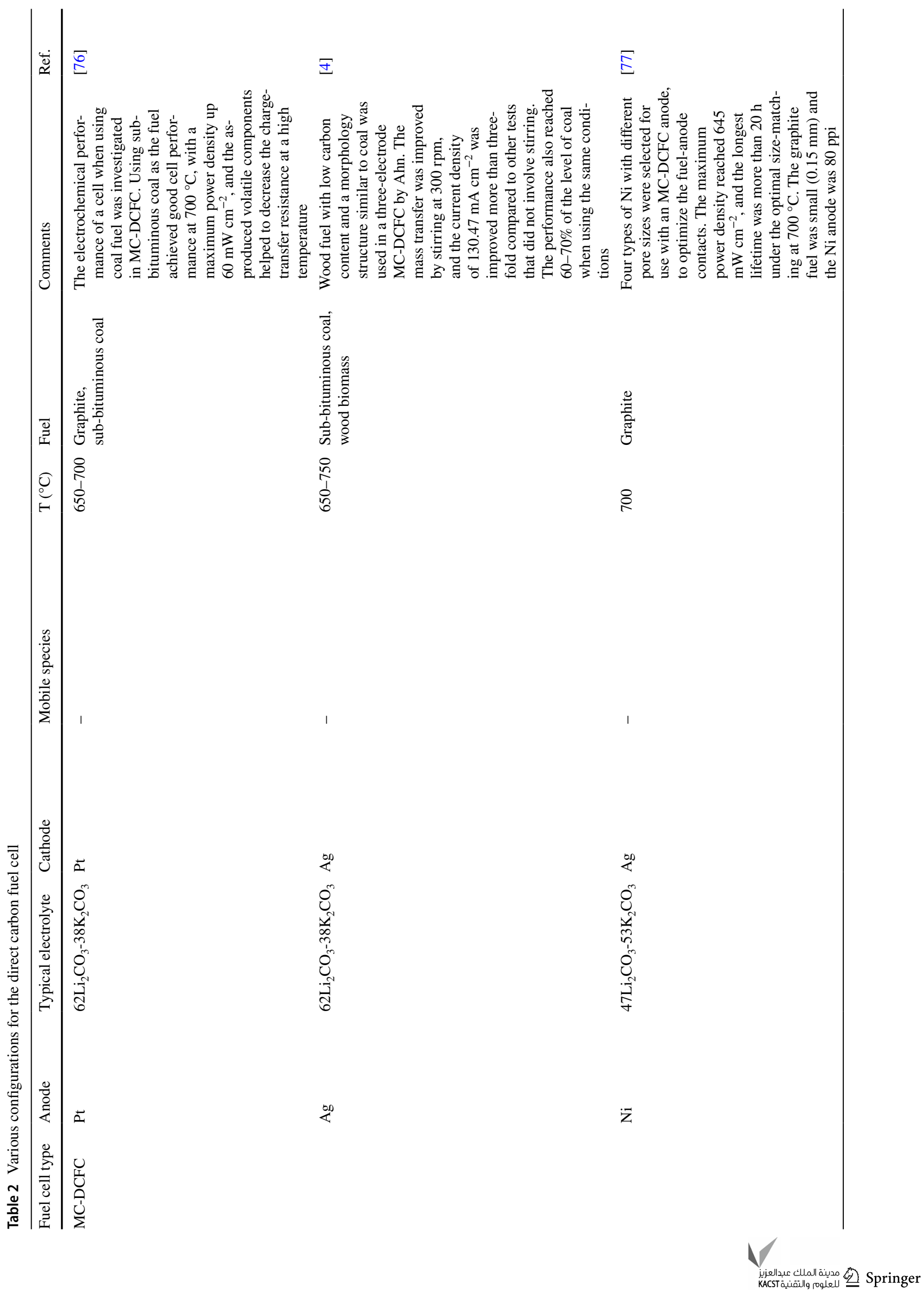




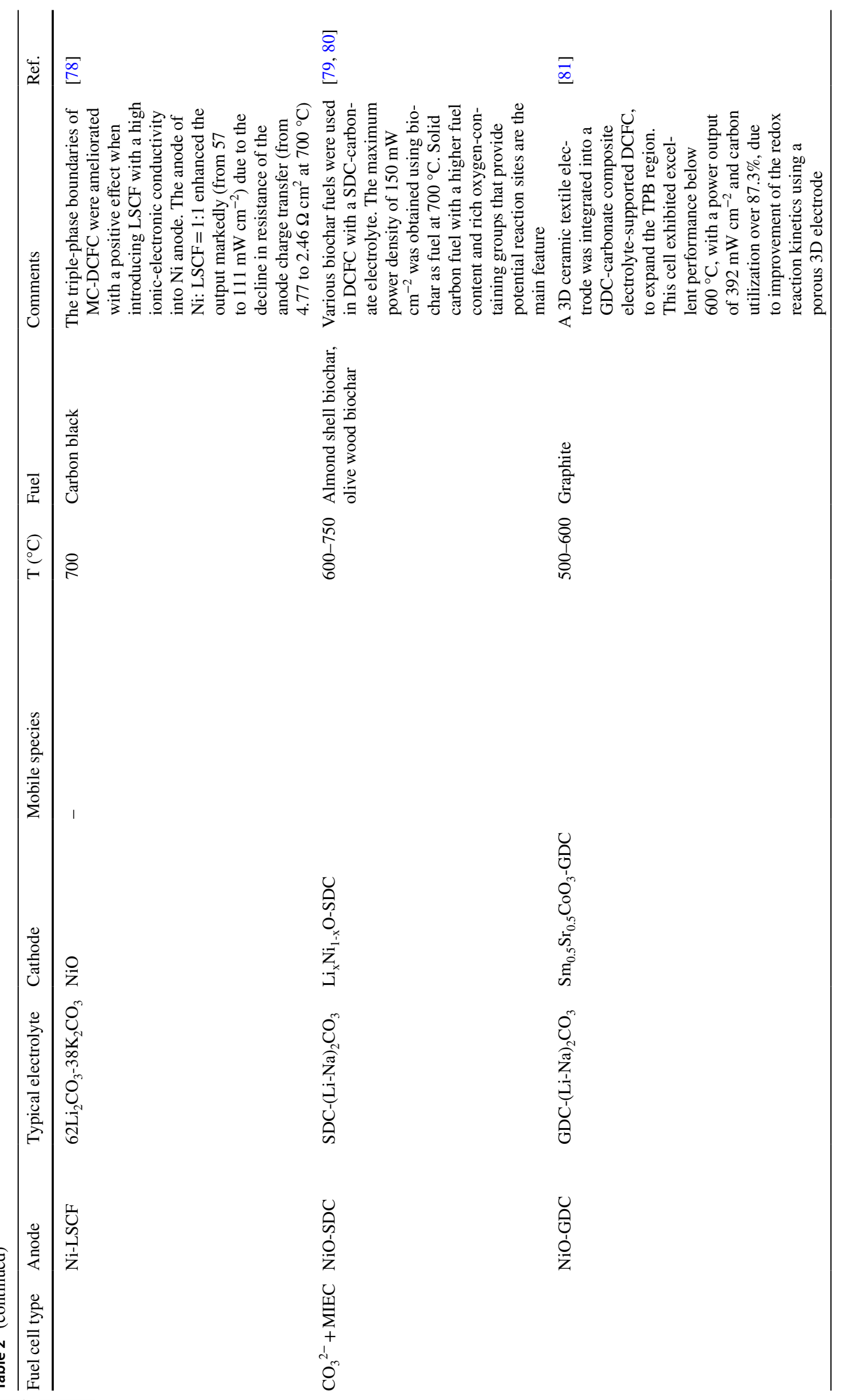




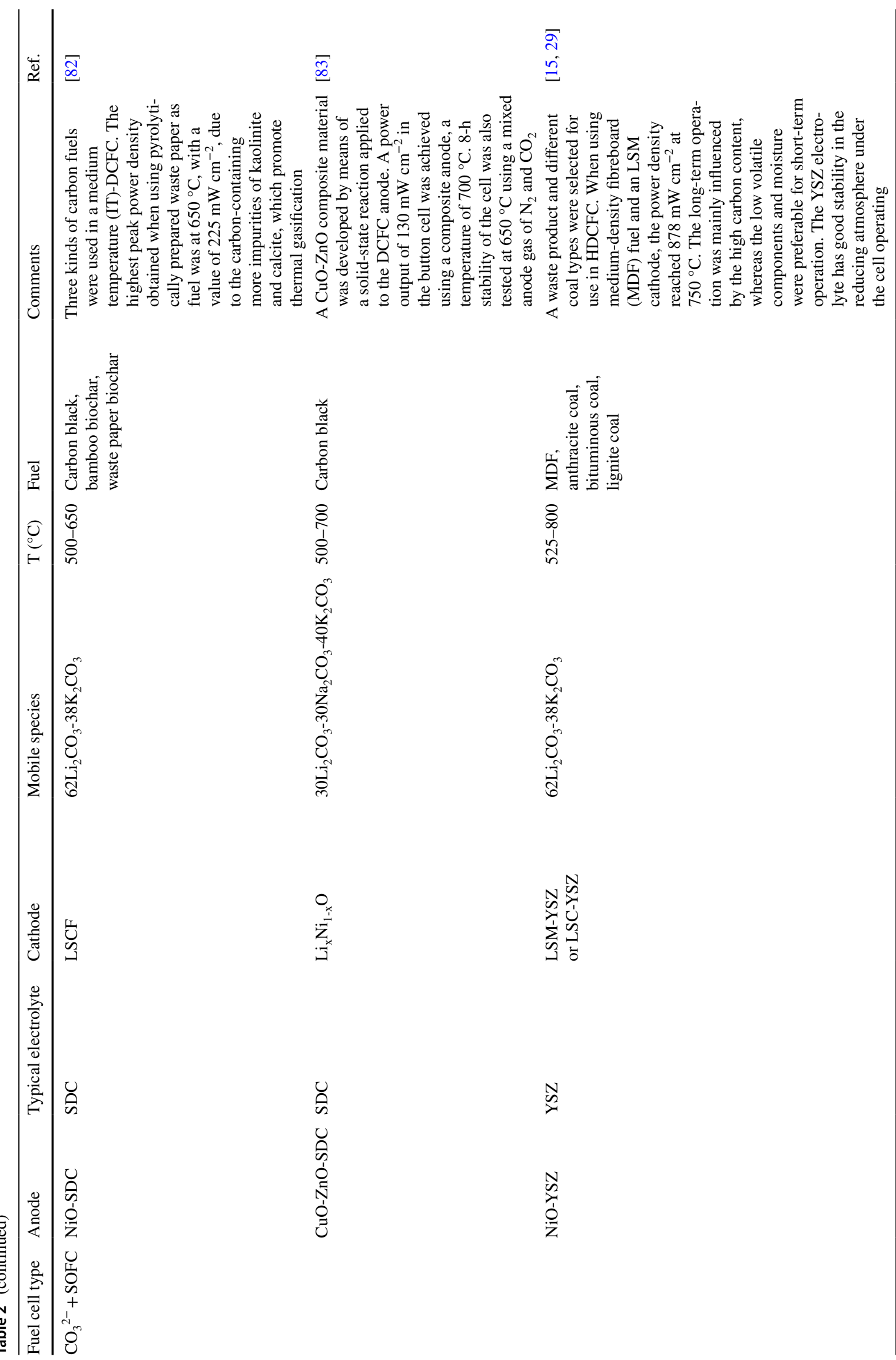


lanthanum strontium cobalt ferrite (LSCF) and MIEC to the $\mathrm{Ni}$ anode, at a molar ratio of $1: 1$, showed a better power density of $111 \mathrm{~mW} \mathrm{~cm}{ }^{-2}$ at $700{ }^{\circ} \mathrm{C}$ compared to the single $\mathrm{Ni}$ anode. The excellent power output is attributed to the decreased ohmic and charge-transfer resistance and the expansion of TPBs. Additionally, Bie et al. [110] designed a novel syringe-type anode, which ensured extended region TPBs by pressing the carbon powder into the molten electrolyte, and preventing carbon oxidation.

\section{$\mathrm{CO}_{3}{ }^{2-}+\mathrm{MIEC}$}

It is well known that ceria-based oxide is a typical transition metal oxide with mixed electronic and ionic conductivity (MIEC). Its doped oxides, including Gd-doped ceria (GDC) and Sm-doped ceria (SDC), have been applied to an intermediate temperature (IT) SOFC ranging from 400 to $700{ }^{\circ} \mathrm{C}$ [111]. The SDC-carbonate composite electrolyte shows excellent conductivity of $10^{-2}$ to $1.0 \mathrm{~S} \mathrm{~cm}^{-1}$ in the range of $400-700{ }^{\circ} \mathrm{C}$, which is better than a pure GDC or SDC $\left(5 \times 10^{-3}-10^{-2} \mathrm{~S} \mathrm{~cm}^{-1}\right)$, and similar to the traditional solid oxide electrolyte-yttrium-stabilized zirconia (YSZ) at $1000{ }^{\circ} \mathrm{C}[112,113]$. Additionally, this composite electrolyte is not subject to corrosion issues in the normal MCFC. This type of composite electrolyte has also now been popularized in DCFC and has shown acceptable performance.

The cell performance was improved when using the composite electrolyte of SDC and carbonate because molten carbonate with mobility can expand the TPB at the anode. Therefore, reduced electrode polarization resistance was often achieved. It was also found that the redox reaction of carbon fuel was enhanced when using doped ceria materials. A diagram of the electrochemical process between the electrolyte and the electrode is presented in Fig. 4. It shows

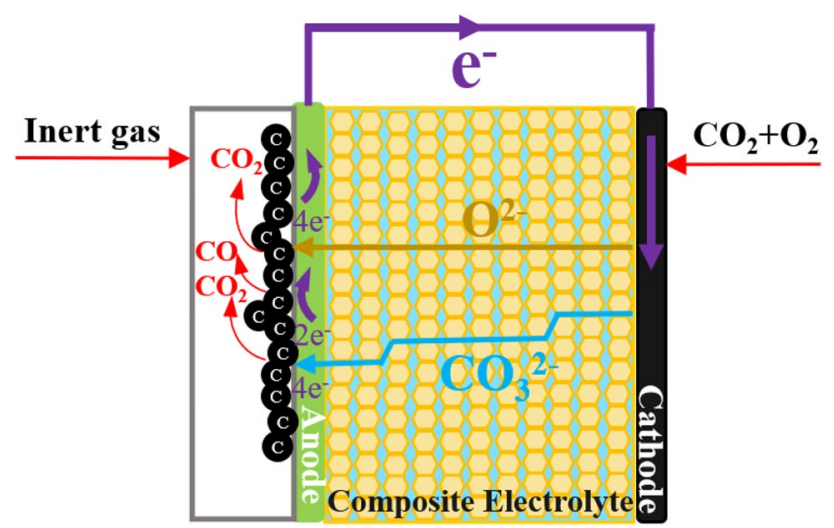

Fig. 4 Schematic of DCFC with a composite electrolyte: $\mathrm{CO}_{2}$ and $\mathrm{O}_{2}$ receive electrons and produce carbonate ion; only $\mathrm{O}_{2}$ receives electrons and produces $\mathrm{O}^{2-}$ at the cathode. Then, the $\mathrm{O}^{2-}$ and carbonate ions are transferred to the anode through a composite electrolyte, and react with carbon to produce $\mathrm{CO}, \mathrm{CO}_{2}$ and electrons that two electrochemical mechanisms might be responsible for forming carbonate ions and oxygen ions in the cathode chamber filled with $\mathrm{O}_{2}$ and $\mathrm{CO}_{2}$ (Eqs. 2 and 15).

In the composite electrolyte of SDC-carbonate, it is apparent that the charged species are carbonate ions and oxygen ions and that carbonate ions are transferred in the molten electrolyte, while oxygen ions are the conducting species within the SDC $[114,115]$. The carbon particles in the anode cavity, part of which is immersed in molten carbonate, combine with carbonate ions, while others are in contact with the electrolyte of SDC directly and react with oxygen ions, which simultaneously release $\mathrm{CO}$ or $\mathrm{CO}_{2}$ and generate electrons (Eqs.1, 7, 16 and 17). $\mathrm{CO}$ can also be produced from Eq. (6) through the Boudouard reaction, with further oxidation by oxygen ions [116].

Despite many studies done on the molten carbonate system to explore the oxidation reactions of carbon, the reaction mechanism is still not fully understood [117].

$\mathrm{O}_{2}+4 \mathrm{e}^{-}=2 \mathrm{O}^{2-}$

$\mathrm{C}+2 \mathrm{O}^{2-}=\mathrm{CO}_{2}+4 \mathrm{e}^{-}$

$\mathrm{C}+\mathrm{O}^{2-}=\mathrm{CO}+2 \mathrm{e}^{-}$

Varieties of carbonaceous fuels used in DCFC with the doped ceria-carbonate composite electrolyte have been reported in literature. Elleuch et al. [79] used lowcost solid carbon-containing coal coke, petroleum coke and almond shell carbonization as fuel for DCFC with an SDC-NiO anode, an SDC- $\left(66 \mathrm{~mol} \% \mathrm{Li}_{2} \mathrm{CO}_{3}-33 \mathrm{~mol} \%\right.$ $\mathrm{Na}_{2} \mathrm{CO}_{3}$ ) electrolyte and $\mathrm{Li}_{\mathrm{x}} \mathrm{Ni}_{1-\mathrm{x}} \mathrm{O}-\mathrm{SDC}$ as the cathode. The results showed that the carbonized-almond shell with more oxygen-containing functional groups has good cell performance at $700{ }^{\circ} \mathrm{C}$, with a power output of $127 \mathrm{~mW} \mathrm{~cm}^{-2}$. The researchers further explored the electrochemical oxidation of carbon using graphite in the same cell [113]. They found that cell performance was improved with a maximum power density of $59 \mathrm{~mW} \mathrm{~cm}^{-2}$ at $700{ }^{\circ} \mathrm{C}$ when adjusting the anode environment $\left(\mathrm{N}_{2}\right.$ atmosphere). In $\mathrm{CO}_{2}$ atmosphere, the value reached $37 \mathrm{~mW} \mathrm{~cm}^{-2}$ [113].

Recently, a dual 3D ceramic textile electrode was integrated into a GDC-carbonate composite electrolyte-supported DCFC, and thus, the TPB region was expanded [118]. Bian et al. [81] developed a unique electrolyte-supported DCFC consisting of a GDC-(67 mol\% $\mathrm{Li}_{2} \mathrm{CO}_{3}-33 \mathrm{~mol} \% \mathrm{Na}_{2} \mathrm{CO}_{3}$ ) electrolyte, a NiO-GDC anode and a $\mathrm{Sm}_{0.5} \mathrm{Sr}_{0.5} \mathrm{CoO}_{3}$-GDC cathode. It exhibited unprecedented cell performance at $600{ }^{\circ} \mathrm{C}$, with a power output of $392 \mathrm{~mW} \mathrm{~cm}^{-2}$ when using graphitic fuel, due to the enhanced charge and mass transfer on the electrode below $600{ }^{\circ} \mathrm{C}$ [81]. High fuel utilization of $87.3 \%$ was also achieved, as the carbon fuel could quickly reach the 
TPBs via the flowing molten carbonate in the cell operation process.

\section{$\mathrm{CO}_{3}{ }^{2-}+\mathrm{SOFC}$}

Recently, HDCFC was combined with SOFC technology and MCFC technology to provide a new way for carbon fuel to reach the reaction region [21]. This method ensures that the molten carbonate is incorporated into the anode cavity, which significantly expands the reaction region from a two-dimensional to a three-dimensional region, and this accelerates the mass transfer to the solid anode/electrolyte. The carbonate serves as a medium to promote the complete oxidation of carbon [23, 119]. In this system, the solid oxide electrolyte separates the anode from the cathode and prevents the diffusion of carbonate to the cathode with no risk of carbonate corrosion on the cathode. Another feature is that no need for the $\mathrm{CO}_{2}$ cycle. The cathode is exposed to air, which simplifies the cell structure.

The first HDCFC was demonstrated by SRI International [120], and was further developed by the University of St Andrews [21, 121, 122], Contained Energy [123] and Technical University of Denmark [124, 125]. An early tubular HDCFC using a Pt cathode and YSZ electrolyte was designed by the University of St Andrews, with the anode nickel mesh placed in a mixture of carbonate and carbon [126]. However, it is difficult to observe the reaction at the anode in this configuration, as the active zones of the electrolyte/electrode are uncertain in a closed-cell above the melting point of the lithium and potassium carbonate $[126,127]$. The researchers at the University of St Andrews also developed a planar button cell with better sealing for improved gas purification [128]. The electrochemical reaction mechanism in the anode was also investigated in detail $[21,122]$. To date, the highest power density was obtained by Jiang et al. [15] using pyrolyzed medium-density fiberboard in HDCFC, which reached $878 \mathrm{~mW} \mathrm{~cm}^{-2}$ at $750{ }^{\circ} \mathrm{C}$.

\section{Reaction mechanism}

HDCFC is based on two typical fuel cells-SOFC and MCFC - in which: the solid oxide electrolyte (which includes YSZ, GDC or SDC) separates the electrode chambers; the molten carbonate electrolyte has fluidity at a high temperature and expands the oxidation reaction area [21]. The oxygen ions reduced from the oxygen molecule are transmitted from the cathode to the anode compartment through the solid oxide electrolyte (as given by Eq. 15). In the anode compartment, carbon particles may be completely oxidized to $\mathrm{CO}_{2}$ or partially oxidized to $\mathrm{CO}$ (Eqs. 16 and 17) $[129,130]$. The OCV value would be $1.02 \mathrm{~V}$, if Eq. 16 was the only anode reaction, regardless of temperature.

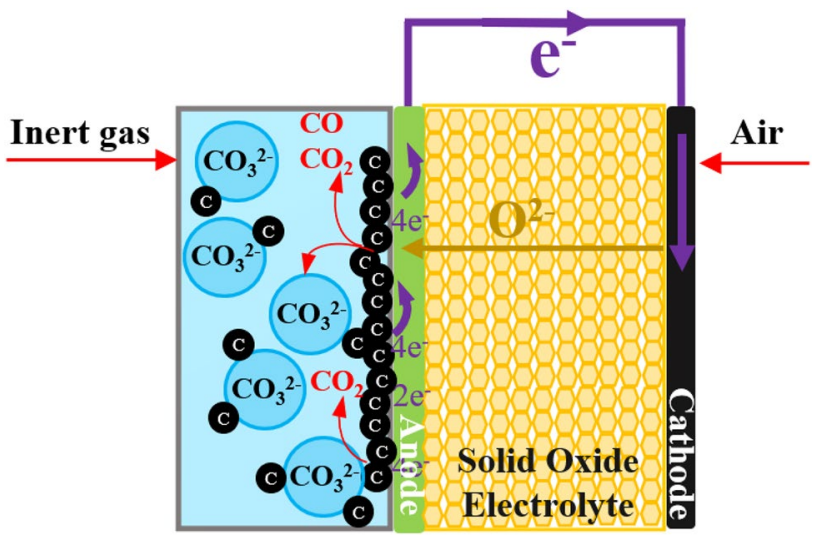

Fig. 5 Schematic diagram of the $\mathrm{SOFC}+\mathrm{MCFC}$ system: $\mathrm{O}_{2}$ gains electrons and then produces $\mathrm{O}^{2-}$ at the cathode; $\mathrm{O}^{2-}$ then passes through a solid oxide electrolyte and arrives at the electrolyte/anode interface, where it reacts with carbon to produce $\mathrm{CO}, \mathrm{CO}_{2}$ and electrons

An OCV of approximately $1.5 \mathrm{~V}$ was observed by a current study, which is higher than the theoretical voltage with working temperatures of $550-700{ }^{\circ} \mathrm{C}$ in HDCFC [119]. A higher OCV value indicates that other reactions are also underway apart from the direct electrochemical oxidation of carbon to $\mathrm{CO}_{2}$. Figure 5 shows that some reactions and some gas production occur in the anode compartment of HDCFC, which is full of $\mathrm{CO}_{2}$ and $\mathrm{CO}$ at the same time. In the anode chamber filled with nitrogen, the reaction processes of carbon (both electrochemical and chemical) are complicated. In the anode, both oxygen ions and carbonate ions are active species of electrochemical oxidation in the slurry of carbon/carbonate [21]. When the number of oxygen ions is sufficiently high, the $\mathrm{CO}_{2}$ could be converted to carbonate ions, which would result in a slow decline of $\mathrm{CO}_{2}$ activity in the molten carbonate, as indicated by Eq. (18). With continued consumption of the oxygen ions, the carbonate ions oxidize carbon to $\mathrm{CO}_{2}$ or $\mathrm{CO}$, as indicated by Eqs. (7 and 8). Carbonate ions then regenerate from oxygen ions and $\mathrm{CO}_{2}$ as indicated by Eq. (18), which maintains the electric charge balance in the molten carbonate solution. Some reports have claimed that the low activity of $\mathrm{CO}_{2}$ could be due to it being dissolved in molten carbonate by physical or chemical methods [131, 132], which may increase the Nernst potential. Nevertheless, the presence of molten carbonate, which facilitates the flow of carbon particles to the anode chamber and expands the TPBs, is expected to act as an electrochemical mediator and accelerate the oxidation reaction kinetics of the carbon particles [13, 41].

$\mathrm{O}^{2-}+\mathrm{CO}_{2}=\mathrm{CO}_{3}^{2-}$

$\mathrm{CO}+\mathrm{O}^{2-}=\mathrm{CO}_{2}+2 \mathrm{e}^{-}$ 
$\mathrm{CO}+\mathrm{CO}_{3}^{2-}=2 \mathrm{CO}_{2}+2 \mathrm{e}^{-}$

In addition, the non-electrochemical reaction of the Boudouard reaction that occurs at $750{ }^{\circ} \mathrm{C}$ has a strong influence on the entire anode reaction, which consumes carbon through a chemical reaction and causes a sharp decrease in current density [28]. But in terms of long-term stability, the influence of current density is not obvious [29]. However, the $\mathrm{CO}$ produced by the reverse Boudouard reaction can also generate electricity through electrochemical oxidation, which contributes to higher-power output [133].

Deleebeeck et al. [124] compared the effects of different anode gases on cell performance and found that introducing pure $\mathrm{CO}_{2}$ could reduce the mass transfer limitation by facilitating the Boudouard reaction or preventing the carbonate decomposition. In addition, introducing $\mathrm{N}_{2}$ leads to a high $\mathrm{OCV}$, due to the movement of $\mathrm{CO}_{2}$ or $\mathrm{CO}$ [134].

Recently, $\mathrm{Li}$ et al. [135] also found that introducing $\mathrm{CO}_{2}$ into the anode chamber could improve cell performance through the electrochemical reaction (Eqs. 19 and 20) at $700-800{ }^{\circ} \mathrm{C}$. However, poor performance by filing $\mathrm{CO}_{2}$ was obtained at $650{ }^{\circ} \mathrm{C}$, as a low temperature is unfavorable for the reverse Boudouard reaction.

(a)

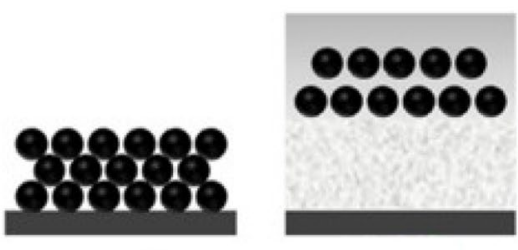

cell I

cell II

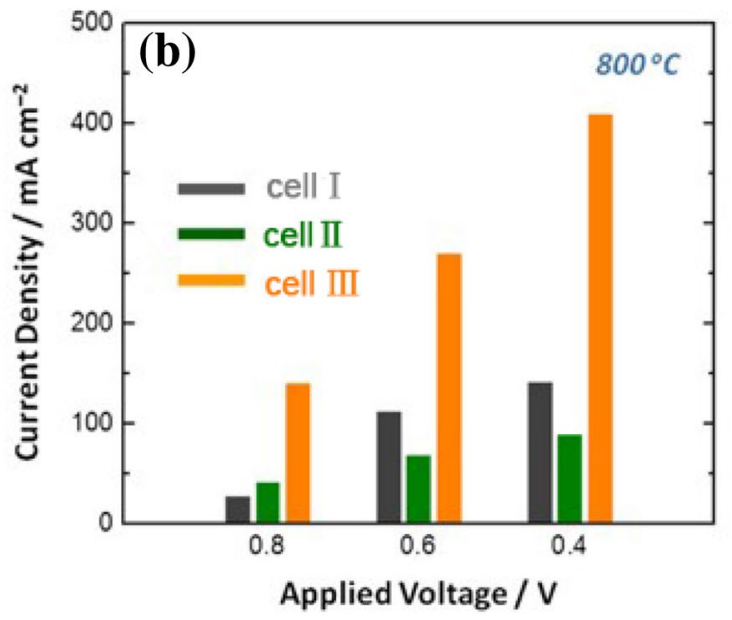

Fig. 6 The relationship between the different contact modes of the anode and the cell performance of DCFC: a three different contact methods for carbon fuel and the anode; $\mathbf{b}$ comparison of current den-
Given this prior research, Lee et al. [136] designed threefuel cells that provided different contacts with the anode and analyzed the oxidation of carbon fuel by observing the current density using different voltages. The various means of contact method between the carbon and anode are presented in Fig. 6a. Cell I, cell II and cell III indicate: direct contact, physically separated, in contact with the carbonate medium. The current density of the cell at $800{ }^{\circ} \mathrm{C}$, when using a different voltage load, is shown in Fig. 6b. It shows that the values of $i_{I}$ and $i_{\text {II }}$ were lower than that of $i_{\text {III }}$ at a given voltage. Therefore, adding carbonate increases the current density significantly, proving that the carbonate ions dominate the oxidation reaction (See Fig. 6c.

Recently, Jiang et al. [137] designed an experiment to investigate the possible reaction active sites at the anode chamber in HDCFC. The configuration of the HDCFC design is shown in Fig. 7a. The current collection wire could be moved to allow easy adjustment of the space between the current collector and the layer at the anode (L), to further ensure that the reactions occur in the area containing the carbon and carbonate. Figure $7 \mathrm{~b}$ and $\mathrm{c}$ show the AC impedance spectra at $700{ }^{\circ} \mathrm{C}$ when using an anode current collector of $\mathrm{Au}$ and $\mathrm{Pt}$ and different Ls. This demonstrates that the ohmic resistance was determined by the location of the current collection with unchanged polarization resistance. The
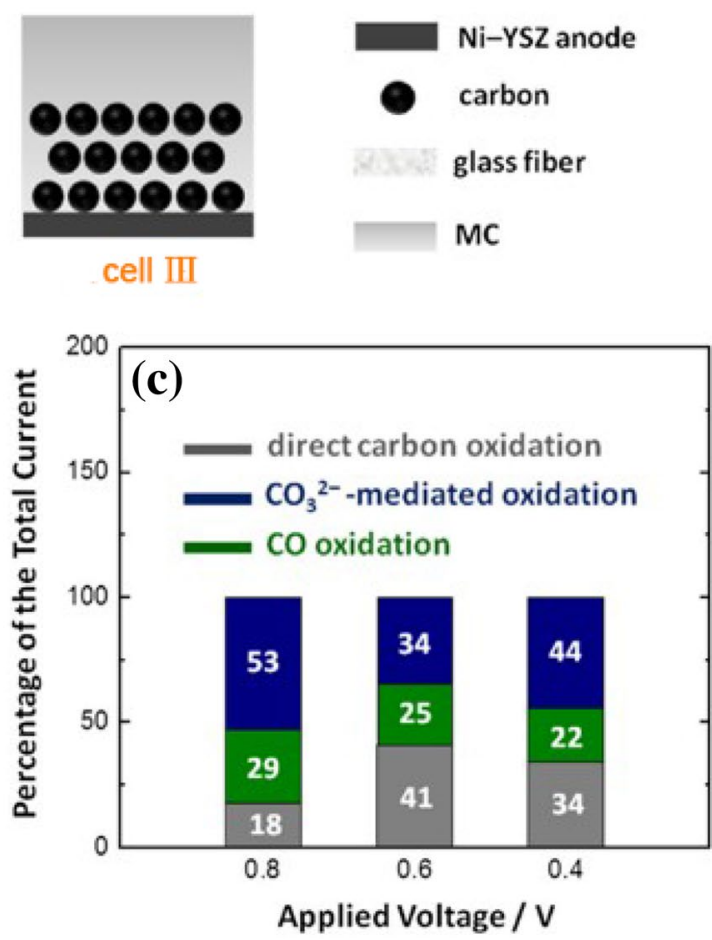

sity using different voltage levels at $800{ }^{\circ} \mathrm{C}$; and c relative contribution value of various reaction mechanisms to the total current. Reproduced from ref. [136] 
(a)

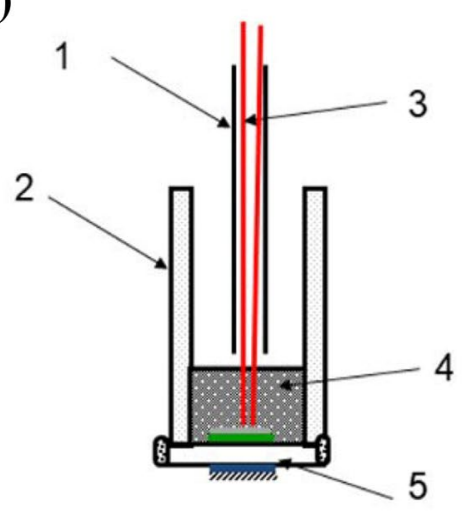

(b)

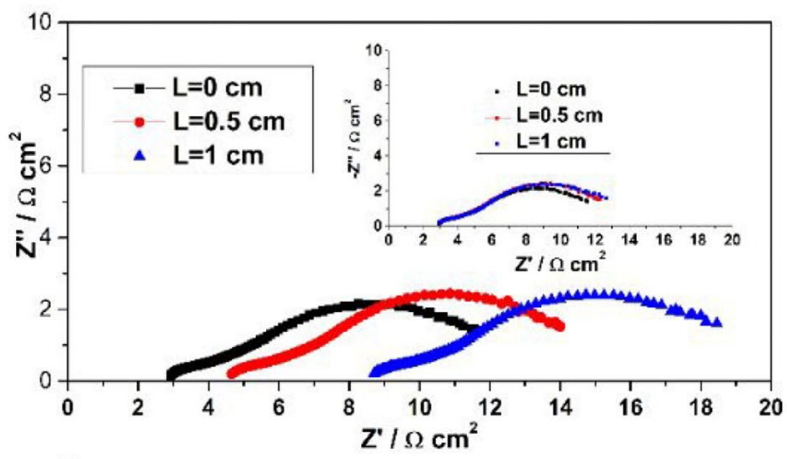

(c)

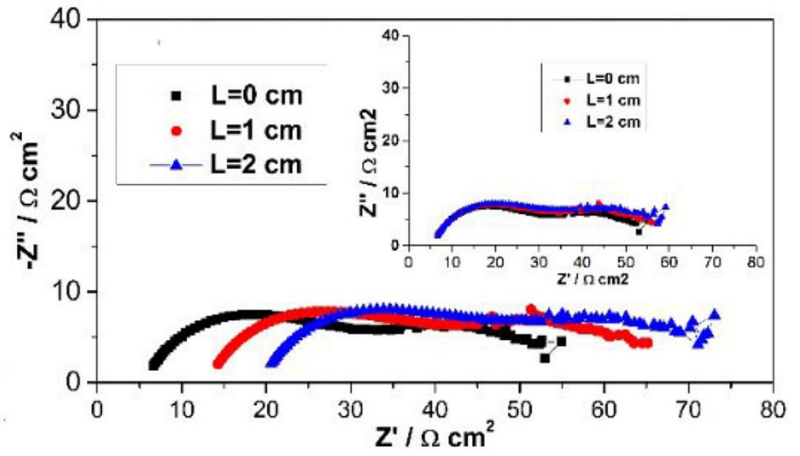

1 Alumina tube, 2 Alumina tube, 3 Wires 4 Mixture of carbon and carbonate 5 Cell

Fig. 7 The electrochemical reaction zone in HDCFC with a NiOYSZ anode, YSZ electrolyte, LSM-YSZ cathode and $62 \mathrm{~mol} \%$ $\mathrm{Li}_{2} \mathrm{CO}_{3}-38 \mathrm{~mol} \% \mathrm{~K}_{2} \mathrm{CO}_{3}$ : a configuration of the HDCFC design with

unchanged polarization resistance with the current collection position also indicates a possible extension from a 2D anode in the TPBs to a 3D area filled with carbon and carbonate for all instances of carbon oxidation.

Apart from the temperature, the carbon oxidation process at the anode also depends on the electrode and electrolyte. Jiang et al. [122] further explored the reaction mechanism of the anode by exchanging the carbonate content in the HDCFC system with a configuration of $\mathrm{NiO}-$ YSZ/YSZ/LSM, while using $62 \mathrm{~mol} \% \mathrm{Li}_{2} \mathrm{CO}_{3}-38 \mathrm{~mol} \%$ $\mathrm{K}_{2} \mathrm{CO}_{3}$ in the anode chamber. They observed reduced polarization resistance of the cell with a carbonate content of $20 \mathrm{~mol} \%$ or $50 \mathrm{~mol} \%$. A different result was found when more carbonate was applied, and higher polarization resistance was achieved when the carbonate increased to $80 \mathrm{~mol} \%$. This finding demonstrates that carbon particles are prevented from reaching the electrode by a high concentration of molten carbonate, which has a limited effect on various carbon oxidation reactions.

Some corrosion and sealing issues are significant concerns when using high carbonate concentrations. Cantero-Tubilla et al. [72] proposed that the liquid phase was related to the carbonate content, and therefore the rate of movement of carbon fuel slowed in the presence of removable current collection wires; $\mathbf{b}$ AC impedance spectrum at $700{ }^{\circ} \mathrm{C}$ with $\mathrm{Au} / \mathrm{NiO}-\mathrm{YSZ} / \mathrm{YSZ} / \mathrm{LSM}-\mathrm{YSZ}$; c AC impedance spectrum at $700{ }^{\circ} \mathrm{C}$ with $\mathrm{Pd} / \mathrm{YSZ} / \mathrm{LSM}-\mathrm{YSZ}$. Reproduced from ref. [137]

high carbonate concentrations. The melt carbonate could result in a concomitant increase in polarization resistance and, consequently, a significant decline in electrochemical output.

\section{Chemical catalysis}

McKee et al. [133-140] used a definite redox cycle and postulated that alkali metal carbonates $\left(\mathrm{Li}_{2} \mathrm{CO}_{3}, \mathrm{Na}_{2} \mathrm{CO}_{3}\right.$, $\mathrm{K}_{2} \mathrm{CO}_{3}$, etc.) produce catalytic activity, which is helpful in the process of gasification of carbon under an oxygen or carbon dioxide atmosphere. In a flowing oxygen atmosphere, carbon-induced decomposition of metal carbonates $\left(\mathrm{M}_{2} \mathrm{CO}_{3}\right)$ into metal oxides $\left(\mathrm{M}_{2} \mathrm{O}\right)$, as shown Eq. (21) [138]:

$\mathrm{M}_{2} \mathrm{CO}_{3}+\mathrm{C}+\mathrm{O}_{2}=\mathrm{M}_{2} \mathrm{O}+2 \mathrm{CO}_{2}$

At a higher temperature, $\mathrm{M}_{2} \mathrm{O}$ is further oxidized to peroxide or higher oxide $\left(\mathrm{M}_{2} \mathrm{O}_{1+\mathrm{n}}\right)$, and eventually reduced to $\mathrm{M}_{2} \mathrm{O}$ by carbon, which completes the redox cycle-see Eqs. $(22,23)$ [139].

$\mathrm{M}_{2} \mathrm{O}+\frac{n}{2} \mathrm{O}_{2}=\mathrm{M}_{2} \mathrm{O}_{1+\mathrm{n}}$ 
$\mathrm{M}_{2} \mathrm{O}_{1+\mathrm{n}}+\mathrm{nC}=\mathrm{M}_{2} \mathrm{O}+\mathrm{nCO}$

Nevertheless, it is unlikely that the reaction of the oxide-peroxide cycle will take place in a flowing carbon dioxide atmosphere because the conversion of $\mathrm{M}_{2} \mathrm{CO}_{3}$ to $\mathrm{M}_{2} \mathrm{O}$ is difficult. Instead, $\mathrm{M}_{2} \mathrm{CO}_{3}$ is reduced to the elemental state, while $\mathrm{C}$ is oxidized to $\mathrm{CO}$ :

$\mathrm{M}_{2} \mathrm{CO}_{3}+2 \mathrm{C}=2 \mathrm{M}+3 \mathrm{CO}$

Then, the metal element generates metal oxide in the carbon dioxide atmosphere:

$2 \mathrm{M}+\mathrm{CO}_{2}=\mathrm{M}_{2} \mathrm{O}+\mathrm{CO}$

After that, carbonate is formed by the metal oxide and carbon dioxide, which completes a cycle reaction [138]:

$\mathrm{M}_{2} \mathrm{O}+\mathrm{CO}_{2}=\mathrm{M}_{2} \mathrm{CO}_{3}$

Nagase et al. [141] proposed that some metal carbonates also had an influence on the reverse Boudouard reaction in an inert atmosphere, which acted as the catalytic media in the process of electrochemical oxidation or gasification of carbon.

Recently, Li et al. [22] studied the reaction mechanism of the HDCFC anode filled with $\mathrm{N}_{2}$. These researchers found that more $\mathrm{CO}$ was produced using eutectic salts $\left(\mathrm{Li}_{2} \mathrm{CO}_{3}-\mathrm{K}_{2} \mathrm{CO}_{3}\right)$ as the catalyst media, than the absence of carbonate, which therefore improved cell performance. Two reactions produced the carbon dioxide (Eq. 27) and the carbon monoxide (Eq. 28), with both converting $\mathrm{M}_{2} \mathrm{CO}_{3}$ to $\mathrm{M}_{2} \mathrm{O}$ :

$\mathrm{M}_{2} \mathrm{CO}_{3}+\mathrm{C}+2 \mathrm{O}^{2-}=\mathrm{M}_{2} \mathrm{O}+2 \mathrm{CO}_{2}+4 \mathrm{e}^{-}$

$\mathrm{M}_{2} \mathrm{CO}_{3}+\mathrm{C}+\mathrm{O}^{2-}=\mathrm{M}_{2} \mathrm{O}+\mathrm{CO}_{2}+\mathrm{CO}+2 \mathrm{e}^{-}$

Lastly, more $\mathrm{CO}$ and electrons were generated by series of reactions (Eqs. 29 and 30) than in an oxygen atmosphere:

$\mathrm{M}_{2} \mathrm{O}+\mathrm{nO}^{2-}=\mathrm{M}_{2} \mathrm{O}_{1+\mathrm{n}}+2 \mathrm{ne}^{-}$

$\mathrm{M}_{2} \mathrm{O}_{1+\mathrm{n}}+\mathrm{nC}=\mathrm{M}_{2} \mathrm{O}+\mathrm{nCO}$

\section{Issues with the presence of carbonate}

Even though DCFC is being developed continuously, some issues, like materials and technology, must be addressed. Most molten carbonates are corrosive and reactive, which raises widespread concern about the thermal corrosion and chemical stability of cell materials and the chemical composition of solid fuels. Besides the ash of solid carbon fuels, the wettability of carbonates also affects cell performance. These problems ultimately lead to a significant reduction in conversion efficiency and long-term stability.

\section{Corrosion}

The highly corrosive action of molten carbonate has prevented progress from being made with MCFC technology. From 1996 to 2006, the cell lifetime was greatly increased from just a few months to 2 years [142]. However, when various carbonates are used as the electrolyte contacted by cell components, it still results in thermal corrosion attacks (such as oxidation, carburization and flux reactions) at high operating temperatures [143]. The corrosion issue gives rise to severe challenges in improving the chemical and physicochemical stability of electrode materials for MCFC. Although some new power generation devices are emerging, stability has always been an issue when developing new technologies.

At present, nickel is one of the most widely used electrode materials because of its low price and good performance in conductivity and electro-catalytic ability. However, $\mathrm{Ni}$ and $\mathrm{NiO}$ are easily dissolved into the molten carbonate, which causes an internal short-circuit in MCFC or a short lifespan [144]. It was reported that the $\mathrm{Ni} / \mathrm{NiO}$ solubility in carbonate could be reduced by adding some oxides (e.g., $\mathrm{SrO}$ or $\mathrm{MgO}$ [140-148]) or carbonates (e.g., $\mathrm{CaCO}_{3}, \mathrm{BaCO}_{3}$, or $\left.\mathrm{SrCO}_{3}[146,149]\right)$ to alkali carbonate, due to the change in the $\mathrm{pH}$ value of the solution.

Doping a rare-earth metal [150] or a rare-earth metal oxide (such as $\mathrm{La}_{2} \mathrm{O}_{3}, \mathrm{Y}_{2} \mathrm{O}_{3}$, and $\mathrm{Yb}_{2} \mathrm{O}_{3}$ ) [146-153] is another practical approach to protect the nickel or nickel oxide electrode against dissolution in molten carbonate. For example, a $\mathrm{Ni}-\mathrm{Ce}$ cathode showed more durability $\left(136 \mathrm{~mW} \mathrm{~cm}^{-2}\right.$ during $2100 \mathrm{~h}$ ) than a commercial $\mathrm{Ni}$ cathode material (but the voltage decreased from 120 to $108 \mathrm{~mW} \mathrm{~cm}^{-2}$ in $1000 \mathrm{~h}$ ) [150]. Further, Liu et al. [154] observed that adding the rare-earth metal Dy to a mixture of $\mathrm{Li}_{2} \mathrm{CO}_{3}$ and $\mathrm{K}_{2} \mathrm{CO}_{3}$ in a mole ratio of $62: 38$ could reduce the $\mathrm{NiO} / \mathrm{Ni}$ passive anodic current, inhibiting the outward diffusion of $\mathrm{Ni}$ at $650{ }^{\circ} \mathrm{C}$, and eventually increase the resistant ability to corrosion.

In terms of HDCFC, the solid oxide electrolyte separates the two electrodes and prevents the cathode from carbonate corrosion. Nevertheless, the chemical compatibility between the electrolyte and the carbonate is essential because of the contact-attack. Suski et al. [155] reported on a double-cell with YSZ and an electrolyte of 53\% $\mathrm{Li}_{2} \mathrm{CO}_{3}-47 \% \mathrm{Na}_{2} \mathrm{CO}_{3}$, with the OCV of $\mathrm{O}_{2}+\mathrm{Ar} / \mathrm{YSZ} / \mathrm{Au}$ at TPBs being similar to the OCV value of the reference electrode over $1000 \mathrm{~h}$ of operation. The long operation 

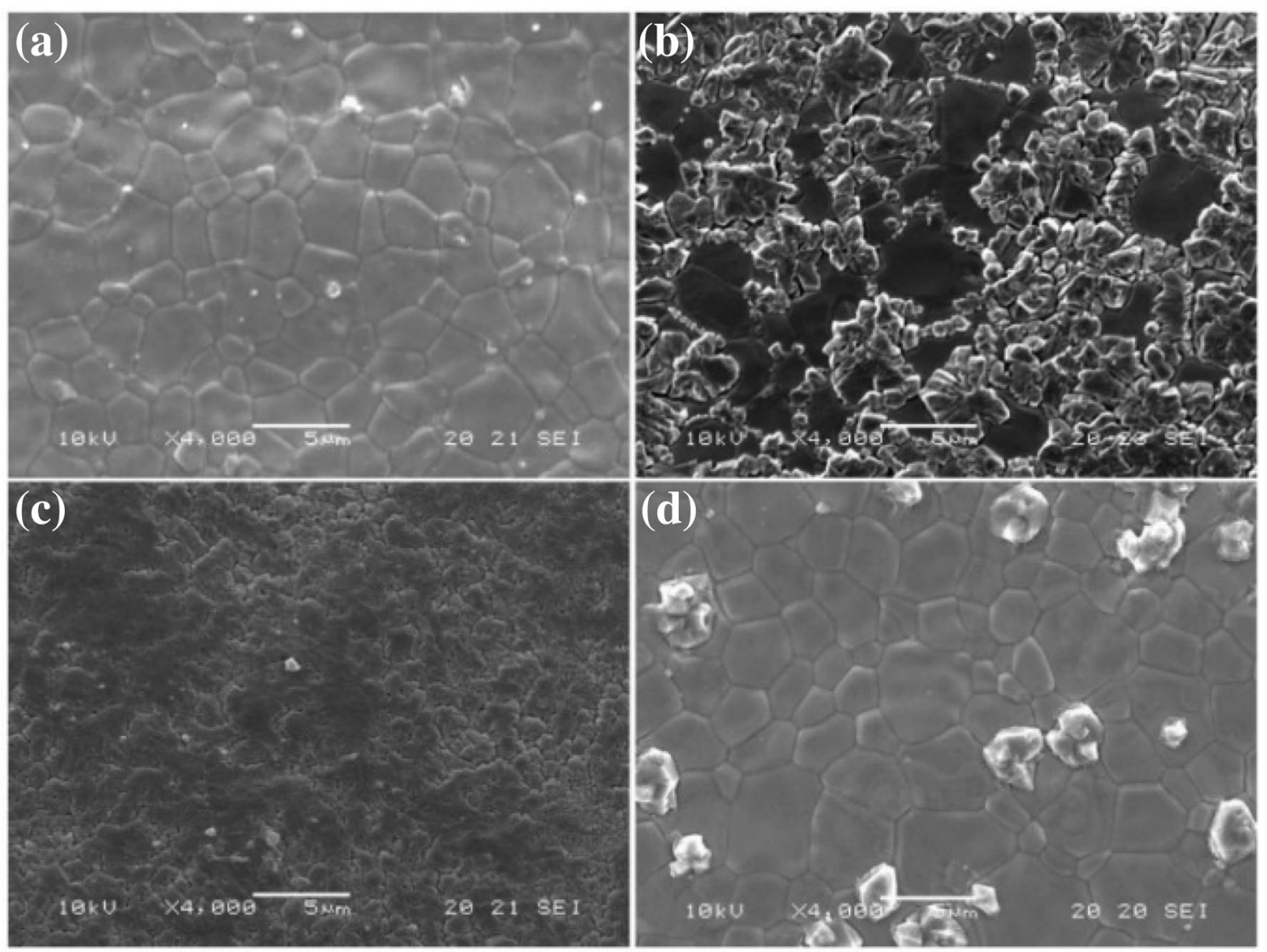

Fig. 8 SEM images of the YSZ surface with the corrosion test in Li-K carbonate at $700{ }^{\circ} \mathrm{C}$ for $10 \mathrm{~h}$ : $\mathbf{a}$ before the corrosion test; $\mathbf{b}$ in air; $\mathbf{c}$ in Ar; d in $5 \% \mathrm{H}_{2} /$ Ar. Reproduced from ref. [15]

hours indicate that the kinetics of the chemical reaction between $\mathrm{YSZ}$ and $\mathrm{Li}_{2} \mathrm{CO}_{3}-\mathrm{Na}_{2} \mathrm{CO}_{3}$ is very slow. However, another report used XRD analysis to determine that YSZ immersed in $\mathrm{Li}_{2} \mathrm{CO}_{3}-\mathrm{K}_{2} \mathrm{CO}_{3}$ at $700{ }^{\circ} \mathrm{C}$ for 10 days was converted to lithium zirconate, but with no change $\mathrm{K}_{2} \mathrm{CO}_{3}-\mathrm{Na}_{2} \mathrm{CO}_{3}$ [126].

Jiang et al. [15] did a more detailed investigation of YSZ corrosion. First, they confirmed that the YSZ of 5-10 $\mu \mathrm{m}$ did not change for $13 \mathrm{~h}$ in an atmosphere of $97-3 \% \mathrm{H}_{2} \mathrm{O}$. Then, several corrosion experiments were done on the YSZ electrolyte in molten carbonate of $62 \mathrm{~mol} \% \mathrm{Li}_{2} \mathrm{CO}_{3}-38 \mathrm{~mol} \%$ $\mathrm{K}_{2} \mathrm{CO}_{3}$ when using different atmospheres at $700{ }^{\circ} \mathrm{C}$ for $10 \mathrm{~h}$. Figure 8 shows the corrosion of the YSZ surface when using different atmospheres. With the air atmosphere, the grain boundaries of YSZ are destroyed and new particles appear, as shown in Fig. 8b, which may be due to the formation of $\mathrm{Li}_{2} \mathrm{ZrO}_{3}, \mathrm{~K}_{2} \mathrm{ZrO}_{3}$ or $\mathrm{LiKZrO}_{3}$ [151-158]. Some wrinkles appear on the surface of YSZ and the grain boundaries become inconspicuous in a reducing atmosphere, as shown in Fig. 8c, but less significantly than in the air test. There is no significant change after testing performance using $5 \%$ $\mathrm{H}_{2}-95 \%$ Ar, as shown in Fig. 8d. The insignificant change is possible because of the formation of $\mathrm{Li}_{2} \mathrm{ZrO}_{3}$ being prevented in a reducing atmosphere [159].

The researchers used the basicity model of Lux-Flood to explain the experimental result. The formation of oxides and superoxides was more likely to occur in an oxygen environment, which was the primary reason for corrosion [43]. It is common to purge a carrier gas (e.g., $\mathrm{N}_{2}$ or $\mathrm{CO}_{2}$ ) in the anode chamber. The electrolyte material, YSZ, is either in the reducing environment at the interface of the electrolyte/ anode or in the oxidizing environment at the interface of the electrolyte/cathode. Therefore, it is necessary to investigate the stability of YSZ in both the reducing atmosphere and the oxidizing atmosphere to simulate both operating conditions [159, 160]. According to Xu et al. [161], YSZ is a good choice of electrolyte for HDCFC, due to the reducing atmosphere of the anode chamber.

The doped cerium oxide-based material is a typical solid electrolyte in DCFC that shows good stability below $650{ }^{\circ} \mathrm{C}$, due to the complete microstructure being maintained at $650{ }^{\circ} \mathrm{C}$ and $10 \% \mathrm{H}_{2}-90 \% \mathrm{~N}_{2}$ for $1000 \mathrm{~h} \mathrm{[162].} \mathrm{Xu}$ et al. [161] further explored the stability of SDC in $62 \mathrm{~mol} \%$ $\mathrm{Li}_{2} \mathrm{CO}_{3}-38 \mathrm{~mol} \% \mathrm{~K}_{2} \mathrm{CO}_{3}$ in air, and found that YSZ easily reacted with $\mathrm{K}_{2} \mathrm{CO}_{3}$ to form $\mathrm{Li}_{2} \mathrm{ZrO}_{3}$ at $700{ }^{\circ} \mathrm{C}$ after 10 days

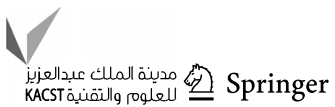



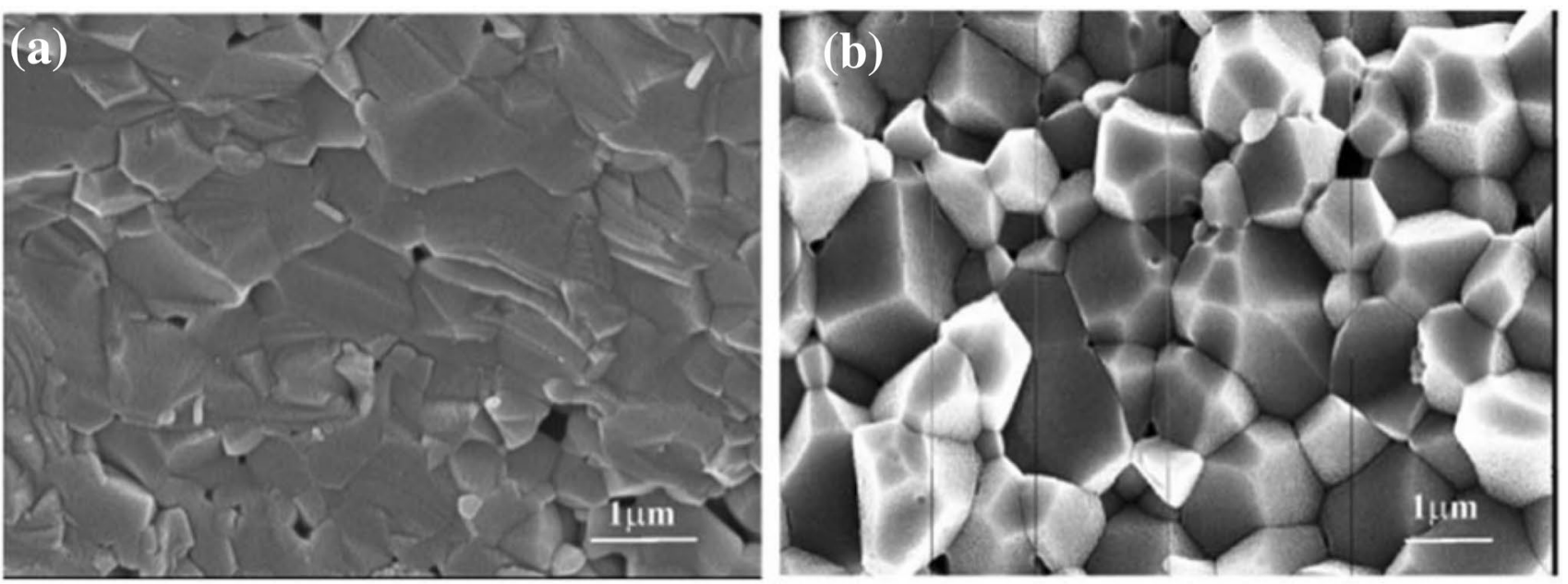

Fig. 9 Cross section of the SDC for the corrosion test in Li-K carbonate at $700{ }^{\circ} \mathrm{C}$ in an air atmosphere for 10 days: a before the corrosion test; $\mathbf{b}$ after the corrosion test. Reproduced from ref. [161]

of testing. And, there is no new phase formation in the SDC sample when using the same conditions. This suggests that SDC is more resistant to corrosion than YSZ, when using air. Although there was no impurity formation of SDC at $700{ }^{\circ} \mathrm{C}$ after 10 days in air, cracks appeared at the grain boundaries [163]. This suggests that crystal boundaries might be the most preferred site for corrosion development [163], as shown in Fig. 9. In addition, the resistance result also showed an insignificant increase in the ohmic resistance of the SDC electrolyte at $650{ }^{\circ} \mathrm{C}$ during the 70 -h testing, which may be due to the slow corrosion rate along the grain boundary. As mentioned, the corrosion of molten carbonate can be ameliorated by different methods, but cannot be avoided. Therefore, it is vital to develop nascent corrosionresistant materials, to maximize the advantages of carbonate for DCFC devices.

\section{Ash}

Solid carbon fuels come from a wide range of sources and have a unique constituency. The molten carbonate is likely to change chemically due to interaction with some ash components, including heavy metals and their oxides, sulfides and chlorides, which ultimately lead to cell failure [74]. However, some metals in ash have a positive effect on cell performance. For example, $\mathrm{Cao}, \mathrm{MgO}$ and $\mathrm{Fe}_{2} \mathrm{O}_{3}$ have a catalytic effect on the oxidation reaction of solid carbon, which increases the current density [24]. A mixture of $\mathrm{Fe}_{\mathrm{m}} \mathrm{O}_{\mathrm{n}}, \mathrm{Li}_{2} \mathrm{O}, \mathrm{K}_{2} \mathrm{O}$ and $\mathrm{CaO}$ is the catalyst for the Boudouard reaction [26] and it can improve the reaction activity and electrochemical performance of the fuel [164]. Therefore, studying the effect of impurities in the ash on cell materials is key to improving the performance of DCFC.
It has been reported that coal with a low ash content shows better cell performance than high ash [29, 160-168]. Ju et al. [169] compared the electrochemical performance of different grades of coal, and found that ash-free coal (low ash content) exhibited the most prolonged stability (300 min at $50 \mathrm{~mA} \mathrm{~cm}^{-2}$ and $900{ }^{\circ} \mathrm{C}$ ), while the raw coal was under operation for $50 \mathrm{~min}$ before failure due to blockage of the anode channel by ash and thus prevention of the reaction. The high ash content in raw coal is considered detrimental to the short-term stability with a Ni-YSZ anode, as the ash blocks the anode and causes contact between the reaction interface and the carbon interface during cell operation [167].

One study reported that when using $\mathrm{Al}_{2} \mathrm{O}_{3}, \mathrm{SiO}_{2}$ and $\mathrm{TiO}_{2}$ from coal ash, it is easy to generate a passivating membrane on the electrode interface during operation of the cell, which leads to passivation of the electrode [74]. In particular, $\mathrm{SiO}_{2}$ is likely to react with carbonate electrolytes, to generate $\mathrm{CO}_{2}$ and $\mathrm{M}_{2} \mathrm{SiO}_{3}$ (where $\mathrm{M}=\mathrm{Li}, \mathrm{Na}, \mathrm{K}$ ) in $\mathrm{MCFC}$, leading to additional electrochemical reactions [170]. Tulloch et al. [171] reported that coal with about $70 \mathrm{wt} \% \mathrm{SiO}_{2}$ ash showed a significant decrease in current density for MC-DCFC, as $\mathrm{SiO}_{2}$ inhibits the oxidation behavior of carbon.

Recently, different pretreatment methods have been proposed to remove unwanted impurities and enhance cell performance [167-175]. Eom et al. [172] reported that using $\mathrm{HCl}$ to pre-treat coal could ensure maximum reduction of ash content and the sensitivity of cell performance to surface silicon content may be reduced when the temperature is higher than $733{ }^{\circ} \mathrm{C}$ because $\mathrm{Li}_{2} \mathrm{SiO}_{3}$ can be completely decomposed at $733{ }^{\circ} \mathrm{C}$ [176]. Xie et al. [174] modified bituminous coal with acetic acid, and effectively removed ash of about $84 \mathrm{wt} \% \mathrm{Si}$ and $64 \mathrm{wt} \% \mathrm{Al}$, to optimize cell performance. 
It has been reported that some impurities in ash may promote an electrode reaction, e.g., $\mathrm{CaO}, \mathrm{MgO}$ and $\mathrm{Fe}_{2} \mathrm{O}_{3}$ could improve the current density slightly by acting as a catalyst in MC-DCFC [24, 177]. Cai et al. [39] employed orchid leaf char in SO-DCFC with yttrium-stabilized zirconia electrolyte and an Ag-GDC electrode. The researchers concluded that the natural $\mathrm{Ca}$ in biochar derived from orchid tree leaves exerted a catalytic effect on the reverse Boudouard reaction and enhanced the performance of DCFC. Then, they loaded $5 \% \mathrm{Ca}$ on wheat straw char in the same cell configuration and recorded a higher-power performance $\left(258 \mathrm{~mW} \mathrm{~cm}^{-2}\right)$ compared to that of unloading char $\left(197 \mathrm{~mW} \mathrm{~cm}^{-2}\right)$ at $700{ }^{\circ} \mathrm{C}$ [178]. Hao et al. [36] further confirmed the positive effect of calcite and magnesium calcite in magazine waste paper, which indicated that more amorphous carbon exhibited a higher degree of carbon oxidation also catalyzed the gasification reaction of carbon fuel and delivered a higherpower density.

Recently, a DCFC supported by an SDC-(67\% Li-33\% $\mathrm{Na})_{2} \mathrm{CO}_{3}$ composite molten carbonate showed excellent cell performance $\left(378 \mathrm{~mW} \mathrm{~cm}^{-2}\right)$ at an operating temperature of $750{ }^{\circ} \mathrm{C}$. The enhanced cell performance was because the $\mathrm{KCl}$ in raw reed ash increases the degree of structural disorder of biochar during the pyrolysis process, which leads to the high oxidation activity of reed char [179].

\section{Wetting}

Complete wetting of the carbon particles in eutectic carbonate is critical for the charge transfer at the TPBs zone [180, 181], as this is a dominant factor in ensuring uninterrupted round-the-clock power generation by the DCFC. During the operating process, the eutectic carbonate is completely diffused and penetrates the carbon pores. Therefore, the potential of a stable cell can be reached [49]. When measuring the contact angle of a graphite rod in $62 \mathrm{~mol} \% \mathrm{Li}_{2} \mathrm{CO}_{3}-38 \mathrm{~mol} \%$ $\mathrm{K}_{2} \mathrm{CO}_{3}$ at $520-560{ }^{\circ} \mathrm{C}$, Chen et al. [182] found that wetting of carbon in carbonate is driven by capillary force, as well as being largely determined by $\mathrm{CO}$ bubbles produced from the reverse Boudouard reaction. The OCV increases from 0.5 to $0.81 \mathrm{~V}$ during the process of wetting, which contributes to the adsorption of $\mathrm{CO}$ on the surface. Therefore, no matter what carbonate is employed in DCFC, as long as the solid carbon is completely soaked in the molten carbonate to form the interface where the carbon oxidation reaction occurs, the electrons can be continuously generated and transferred.

The wettability of solid carbon fuel in a molten carbonate is enhanced by pre-treatment to increase the surface area and the pore volume of the carbon particles [183]. The effect of base or acid pre-treatment on the electrochemical activity of carbon in lithium and potassium carbonate has also been examined [183], with $\mathrm{HF}, \mathrm{HNO}_{3}$ and $\mathrm{NaOH}$ are the common acid and base materials used. Of all the samples, activated carbon pre-treated with HF exhibited the highest electro-oxidation activity, with an increased current of approximately $50 \mathrm{~mA} \mathrm{~cm}^{-2}$. The enhanced current is because HF pre-treatment increases the porosity and surface area of the carbon particles, forming a double electrical layer that facilitates electron transfer of carbon during anodization.

It has also been shown that carbon particle wettability relies on carbonate composition. Watanabe et al. [184] indicated that the surface tension of solid carbon could be reduced by lowering the amount of sodium carbonate and thus improving its wettability. The test results showed that carbon particles had a better wetting effect in a ternary carbonate of $12.2 \mathrm{~mol} \% \mathrm{Li}_{2} \mathrm{CO}_{3}-25 \mathrm{~mol} \% \mathrm{Na}_{2} \mathrm{CO}_{3}-62.8 \mathrm{~mol} \%$ $\mathrm{K}_{2} \mathrm{CO}_{3}$ compared to $12.2 \mathrm{~mol} \% \mathrm{Li}_{2} \mathrm{CO}_{3}-45 \mathrm{~mol} \%$ $\mathrm{Na}_{2} \mathrm{CO}_{3}-42.8 \mathrm{~mol} \% \mathrm{~K}_{2} \mathrm{CO}_{3}$, and that a stable OCV of $0.63 \mathrm{~V}$ could be sustained for $45 \mathrm{~min}$.

In terms of DCFC with molten carbonate, the degree of stirring is also an important variable that affects carbon particle wetting. Li et al. [96] observed that mass transfer has been significantly improved at $400 \mathrm{rpm}$, and that current density can be further increased in the whole electrode potential range when the stirring rate is increased up to $600 \mathrm{rpm}$. Improved current density when increasing the stirring rate aligns with the earlier report of Vutetakis et al. [74]. However, the performance of DCFC will be greatly reduced if the stirring rate exceeds a specific value, because the fuel splash phenomenon leads to a fuel shortage [4]. Whether the stirring improves cell performance or not depends on other factors, such as cell operating temperature and electrolyte viscosity [185].

Carbonate has good ionic conductivity but poor electronic conductivity at a high temperature. Although carbon particles with different sizes are dispersed in molten carbonate, the electrochemical oxidation of carbon occurs only in TPBs, thus the percolation limit of carbon particles must be considered, to ensure efficient and continuous power generation [186]. Using highly conductive carbon fuels such as graphite could improve electronic conductivity, but the chemical activity of graphite is very low. At present, molten metal anodes can solve this problem and ensure good conductivity [187]. However, the corrosion issue remains unresolved.

\section{Outlook}

With the increase in environmental concern and the high energy demand, DCFC may provide a clean electrochemical device for generating electricity from solid carbon. The introduction of carbonate in the DCFC system is conducive to improving cell performance of open-circuit voltage and output power. The carbonate accelerates ion transfer as a medium or is a catalyst for carbon oxidation and gasification reaction. 
At present, research on basic theory is still an essential aspect of the development of DCFC. Although various DCFC systems that use carbonate are being developed rapidly, the specific reaction mechanism with carbonate involved in the whole-cell system still lacks sufficient proof of experiments due to the complexity of reactions inside the cell. Therefore, new experimental configurations should be designed. Alternatively, a combination of a theoretical model and experimental tests should be considered, which would be beneficial to cell performance if determined what substances affect the electrode reaction process.

The issue of material corrosion in molten carbonate has not been solved satisfactorily. Despite a plethora of literatures that have been published to solve the problem of corrosion of carbonate in MC-DCFC, there is still no detailed research on the corrosion of carbonate to the solid-state electrolyte for emerging HDCFCs. It is unknown whether adding some carbonates, oxides or rare-earth elements has a positive or negative effect on cell performance. It has been confirmed that the addition of carbonate to the anode favors expanding TPBs, because the fluidity of molten carbonate could promote the transfer of carbon fuel to the anode, resulting in a dramatic improvement of electrochemical reactions. However, carbonate attacks the solid electrolyte. Although SDC has better corrosion resistance than YSZ, the corrosion issue cannot be avoided. Provided that corrosion occurs during the entire cell operation, the cell will degrade quickly and cannot generate power over the long term. Hence, more attention needs to be focused on the carbonate corrosion to other cell components (including solid-state electrolytes), instead of only common electrode materials.

It is well known that the variety of solid carbonaceous fuels is one of the most significant advantages of DCFC. Nonetheless, the carbonate component in DCFC easily reacts with the inorganic salts of fuels ash-especially coal and biomass fuels with a high ash content-which shows various effects on cell performance. For example, a large amount of $\mathrm{Fe}, \mathrm{Mg}$ and $\mathrm{Ca}$ promotes gasification of carbon, while $\mathrm{Si}$ and $\mathrm{Al}$ have a negative effect on the cell performance of DCFC with carbonate. It is difficult to identify the effect of each inorganic salt on cell performance because there is often more than one salt in the fuel.

Removing ash from non-pure carbon fuels such as biomass should also be considered seriously. Pre-treatment should be attempted as an essential treatment method applied to DCFC (including heat treatment, acid or base washing and air plasma, etc.).

Other issues worth mentioning include the effect of pre-treatment on the properties of the fuel itself and the reactivity of the pretreated fuel with carbonates to eventually explore the feasibility of using different renewable carbon-based materials in the cell.
While many cell designs have been developed to provide better continuous power generation, the fluidized bed cell can provide a more convenient feeding mode. Thus, designing different cell configurations is still key to the commercialization of DCFC.

Supplementary Information The online version contains supplementary material available at https://doi.org/10.1007/s40243-021-00197-7.

Acknowledgements The researchers appreciate the funding support provided by the Sichuan Science and Technology Program (Grant number 2019YFH0177, 2021YFH0092), the Zigong Science and Technology Program (Grant number 2019YYJC24, 2020YGJC18) and the Talent Introduction Plan of Sichuan University of Science and Engineering (Grant numbers 2016RCL36, 2016RCL37).

Open Access This article is licensed under a Creative Commons Attribution 4.0 International License, which permits use, sharing, adaptation, distribution and reproduction in any medium or format, as long as you give appropriate credit to the original author(s) and the source, provide a link to the Creative Commons licence, and indicate if changes were made. The images or other third party material in this article are included in the article's Creative Commons licence, unless indicated otherwise in a credit line to the material. If material is not included in the article's Creative Commons licence and your intended use is not permitted by statutory regulation or exceeds the permitted use, you will need to obtain permission directly from the copyright holder. To view a copy of this licence, visit http://creativecommons.org/licenses/by/4.0/.

\section{References}

1. Grove, W.R.: XXIV On voltaic series and the combination of gases by platinum. Phil. Mag. 14(86-87), 127-130 (1839). https://doi.org/10.1080/14786443908649684

2. Behling, N., Managi, S., Williams, M.: Updated look at the application of solid particles in fuel cell technology. 2019 SME Annual Conference and Expo and CMA 121st National Western Mining Conference (2019)

3. Williams, M.C., Horita, T., Yamaji, K., Yokokawa, H.: An application of solid particles in fuel cell technology. KONA Powder Part. J. 25, 153-161 (2007). https://doi.org/10.14356/kona.20070 14

4. Ahn, S.Y., Eom, S.Y., Rhie, Y.H., Sung, Y.M., Moon, C.E., Choi, G.M., Kim, D.J.: Utilization of wood biomass char in a direct carbon fuel cell (DCFC) system. Appl. Energ. 105, 207-216 (2013). https://doi.org/10.1016/j.apenergy.2013.01.023

5. Edison, T.A.: Process of and apparatus for generating electricity. US Patent No 460, 122 (1891)

6. Jacques, W.W.: Method of converting potential energy of carbon into electrical energy. US Patent No 555511 A (1896)

7. Srinivasan, S.: Fuel cells for extraterrestrial and terrestrial applications. J. Electrochem. Soc. 136(2), 41C (1989). https://doi.org/ 10.1149/1.2096647

8. Meibuhr, S.: Review of united states fuel-cell patents issued from 1860 to 1947. Electrochim. Acta. 11(9), 1301-1308 (1966). https://doi.org/10.1016/0013-4686(66)87029-9

9. Haber, F., Bruner, L.: Das Kohlenelement, eine Knallgaskette. Zeitschrift für Elektrochemie und angewandte physikalische Chemie 10(37), 697-713 (1904). https://doi.org/10.1002/bbpc.19040 103702 
10. Weaver, R.D., Leach, S.C., Bayce, A.E., Nanis, L.: Direct electrochemical generation of electricity from coal. SRI International Corp. (1979)

11. Weaver, R.D., Tietz, L., Cubicciotti, D.: Direct use of coal in a fuel cell: Feasibility investigation. SRI International Corp. (1975)

12. Gür, T.M.: Utilization modes for solid carbon conversion in fuel cells. ECS Trans. 25(2), 1099 (2009). https://doi.org/10.1149/1. 3205637

13. Gür, T.M.: Mechanistic modes for solid carbon conversion in high temperature fuel cells. J. Electrochem. Soc. 157(5), B751 (2010). https://doi.org/10.1149/1.3357050

14. Nürnberger, S., Bußar, R., Desclaux, P., Franke, B., Rzepka, M., Stimming, U.: Direct carbon conversion in a SOFC-system with a non-porous anode. Energy Environ. Sci. 3(1), 150-153 (2010). https://doi.org/10.1039/b916995d

15. Jiang, C., Ma, J., Bonaccorso, A.D., Irvine, J.T.S.: Demonstration of high power, direct conversion of waste-derived carbon in a hybrid direct carbon fuel cell. Energy Environ. Sci. 5(5), 6973-6980 (2012). https://doi.org/10.1039/c2ee03510c

16. Hackett, G.A., Zondlo, J.W., Svensson, R.: Evaluation of carbon materials for use in a direct carbon fuel cell. J. Power Sources 168(1), 111-118 (2007). https://doi.org/10.1016/j.jpowsour. 2007.02.021

17. Dicks, A.L.: The role of carbon in fuel cells. J. Power Sources 156(2), 128-141 (2006). https://doi.org/10.1016/j.jpowsour. 2006.02.054

18. Lan, R., Tao, S.: A simple high-performance matrix-free biomass molten carbonate fuel cell without $\mathrm{CO}_{2}$ recirculation. Sci. Advs. 2(8), e1600772 (2016). https://doi.org/10.1126/sciadv. 1600772

19. Dudek, M., Tomczyk, P.: Composite fuel for direct carbon fuel cell. Catal. Today 176(1), 388-392 (2011). https://doi.org/10. 1016/j.cattod.2010.11.029

20. Liu, C., Pu, J., Chen, X., Ma, Z., Ding, X., Zhou, J., Wang, S.: Influence of anode's microstructure on electrochemical performance of solid oxide direct carbon fuel cells. Inter. J. Hydrogen Energy 45(20), 11784-11790 (2020). https://doi.org/10.1016/j. ijhydene.2020.02.119

21. Nabae, Y., Pointon, K.D., Irvine, J.T.S.: Electrochemical oxidation of solid carbon in hybrid DCFC with solid oxide and molten carbonate binary electrolyte. Energy Environ. Sci. 1(1), 148-155 (2008). https://doi.org/10.1039/b804785e

22. Li, S., Jiang, C., Liu, J., Tao, H., Meng, X., Connor, P., Hui, J., Wang, S., Ma, J., Irvine, J.T.S.: Mechanism of enhanced performance on a hybrid direct carbon fuel cell using sawdust biofuels. J. Power Sources 383(15), 10-16 (2018). https://doi.org/10. 1016/j.jpowsour.2018.02.040

23. Jiang, C., Cui, C., Ma, J., Irvine, J.T.S.: Insight into graphite oxidation in a NiO-based hybrid direct carbon fuel cell. Inter. J. Hydrogen Energy 45(17), 10559-10568 (2020). https://doi.org/ 10.1016/j.ijhydene.2019.08.208

24. Li, X., Zhu, Z., De Marco, R., Bradley, J., Dicks, A.: Evaluation of raw coals as fuels for direct carbon fuel cells. J. Power Sources 195(13), 4051-4058 (2010). https://doi.org/10.1016/j.jpowsour. 2010.01.048

25. Lee, C.-G., Kim, W.-K.: Oxidation of ash-free coal in a direct carbon fuel cell. Inter. J. Hydrogen Energy 40(15), 5475-5481 (2015). https://doi.org/10.1016/j.ijhydene.2015.01.068

26. Tang, Y., Liu, J.: Effect of anode and Boudouard reaction catalysts on the performance of direct carbon solid oxide fuel cells. Inter. J. Hydrogen Energy 35(20), 11188-11193 (2010). https:// doi.org/10.1016/j.ijhydene.2010.07.068

27. Jewulski, J., Skrzypkiewicz, M., Struzik, M., Lubarska-Radziejewska, I.: Lignite as a fuel for direct carbon fuel cell system. Inter. J. Hydrogen Energy 39(36), 21778-21785 (2014). https:// doi.org/10.1016/j.ijhydene.2014.05.039
28. Fuente-Cuesta, A., Jiang, C., Arenillas, A., Irvine, J.T.S.: Role of coal characteristics in the electrochemical behaviour of hybrid direct carbon fuel cells. Energy Environ. Sci. 9(9), 2868-2880 (2016). https://doi.org/10.1039/c6ee01461e

29. Jiang, C., Ma, J., Arenillas, A., Bonaccorso, A.D., Irvine, J.T.: Comparative study of durability of hybrid direct carbon fuel cells with anthracite coal and bituminous coal. Inter. J. Hydrogen Energy 41(41), 18797-18806 (2016). https://doi.org/10.1016/j. ijhydene.2016.04.047

30. König, A., Ulonska, K., Mitsos, A., Viell, J.R.: Optimal applications and combinations of renewable fuel production from biomass and electricity. Energy Fuel 33(2), 1659-1672 (2019). https://doi.org/10.1021/acs.energyfuels.8b03790

31. Li, M., Xiao, H., Zhang, T., Li, Q., Zhao, Y.: Activated carbon fiber derived from sisal with large specific surface area for highperformance supercapacitors. ACS Sustain. Chem. Eng. 7(5), 4716-4723 (2019). https://doi.org/10.1021/acssuschemeng. $8 \mathrm{~b} 04607$

32. Rybarczyk, M.K., Li, Y., Qiao, M., Hu, Y.-S., Titirici, M.-M., Lieder, M.: Hard carbon derived from rice husk as low cost negative electrodes in Na-ion batteries. J. Energy Chem. 29, 17-22 (2019). https://doi.org/10.1016/j.jechem.2018.01.025

33. Tiwari, J.N., Dang, N.K., Sultan, S., Thangavel, P., Jeong, H.Y., Kim, K.S.: Multi-heteroatom-doped carbon from waste-yeast biomass for sustained water splitting. Nat. Sustain. 3(7), 556-563 (2020). https://doi.org/10.1038/s41893-020-0509-6

34. Xu, C., Chen, J., Li, S., Gu, Q., Wang, D., Jiang, C., Liu, Y.: $\mathrm{N}$-doped honeycomb-like porous carbon derived from biomass as an efficient carbocatalyst for $\mathrm{H}_{2} \mathrm{~S}$ selective oxidation. J. Hazard Mater. 403(5), 123806 (2021). https://doi.org/10.1016/j.jhazmat. 2020.123806

35. Yu, J., Zhao, Y., Li, Y.: Utilization of corn cob biochar in a direct carbon fuel cell. J. Power Sources 270(15), 312-317 (2014). https://doi.org/10.1016/j.jpowsour.2014.07.125

36. Hao, W., Mi, Y.: Evaluation of waste paper as a source of carbon fuel for hybrid direct carbon fuel cells. Energy 107(15), 122-130 (2016). https://doi.org/10.1016/j.energy.2016.04.012

37. Wang, C., Lü, Z., Li, J., Cao, Z., Wei, B., Li, H., Shang, M., $\mathrm{Su}, \mathrm{C}$.: Efficient use of waste carton for power generation, tar and fertilizer through direct carbon solid oxide fuel cell. Renew. Energy 158, 410-420 (2020). https://doi.org/10.1016/j.renene. 2020.05.082

38. Elleuch, A., Boussetta, A., Yu, J., Halouani, K., Li, Y.: Experimental investigation of direct carbon fuel cell fueled by almond shell biochar: Part I. Physico-chemical characterization of the biochar fuel and cell performance examination. Inter. J. Hydrogen Energy 38(36), 16590-16604 (2013). https://doi.org/10. 1016/j.jjhydene.2013.08.090

39. Cai, W., Zhou, Q., Xie, Y., Liu, J., Long, G., Cheng, S., Liu, M.: A direct carbon solid oxide fuel cell operated on a plant derived biofuel with natural catalyst. Appl. Energy 179(2), 1232-1241 (2016). https://doi.org/10.1016/j.apenergy.2016.07.068

40. Ali, A., Raza, R., Shakir, M.I., Iftikhar, A., Alvi, F., Ullah, M.K., Hamid, A., Kim, J.-S.: Promising electrochemical study of titanate based anodes in direct carbon fuel cell using walnut and almond shells biochar fuel. J. Power Sources. 434, 12 (2019). https://doi.org/10.1016/j.jpowsour.2019.05.085

41. Cherepy, N.J., Krueger, R., Fiet, K.J., Jankowski, A.F., Cooper, J.F.: Direct conversion of carbon fuels in a molten carbonate fuel cell. J. Electrochem. Soc. 152(1), A80-A87 (2005). https://doi. org/10.1149/1.1836129

42. Cisneros, S., Sánchez, C.: Kinetic characterization and molten $\mathrm{KOH}$ fuel cell simulation for dissolved coal oxidation on nickel anodes. J. Electrochem. Soc. 161(14), F1330-F1339 (2014). https://doi.org/10.1149/2.1181412jes 
43. Bie, K., Zhou, H., Fu, P., Liu, Y., Yue, F.: Investigation of the cathode polarization and carbon deposition in a molten carbonate direct carbon fuel cell. J. Appl. Electrochem. 49(6), 585-597 (2019). https://doi.org/10.1007/s10800-019-01307-0

44. Howard, H.: Direct generation of electricity from coal and gas (fuel cells). Chem. Coal Util. 2, 1568-1585 (1945)

45. Liebhafsky, H.A., Cairns, E.J.: Fuel cells and fuel batteries. Guide to their research and development (1968)

46. Cao, D., Sun, Y., Wang, G.: Direct carbon fuel cell: Fundamentals and recent developments. J. Power Sources 167(2), 250-257 (2007). https://doi.org/10.1016/j.jpowsour.2007.02.034

47. Cao, T., Huang, K., Shi, Y., Cai, N.: Recent advances in hightemperature carbon-air fuel cells. Energy Environ. Sci. 10(2), 460-490 (2017). https://doi.org/10.1039/c6ee03462d

48. Giddey, S., Badwal, S.P.S., Kulkarni, A., Munnings, C.: A comprehensive review of direct carbon fuel cell technology. Prog. Energy Combust. 38(3), 360-399 (2012). https://doi.org/10. 1016/j.pecs.2012.01.003

49. Cooper, J.F., Selman, R.: Electrochemical oxidation of carbon for electric power generation: a review. J. Electrochem. Soc. 19(14), 15-25 (2009). https://doi.org/10.1149/1.3220176

50. Gür, T.M.: Critical review of carbon conversion in "carbon fuel cells." Chem. Rev. 113(8), 6179-6206 (2013). https://doi.org/10. 1021/cr400072b

51. Rady, A.C., Giddey, S., Badwal, S.P.S., Ladewig, B.P., Bhattacharya, S.: Review of fuels for direct carbon fuel cells. Energy Fuel 26(3), 1471-1488 (2012). https://doi.org/10.1021/ ef201694y

52. Zhou, W., Jiao, Y., Li, S.D., Shao, Z.: Anodes for carbonfueled solid oxide fuel cells. ChemElectroChem 3(2), 193-203 (2016). https://doi.org/10.1002/celc.201500420

53. Jiang, C., Ma, J., Corre, G., Jain, S.L., Irvine, J.T.S.: Challenges in developing direct carbon fuel cells. Chem. Soc. Rev. 46(10), 2889-2912 (2017). https://doi.org/10.1039/c6cs00784h

54. Glenn, M.J., Allen, J.A., Donne, S.W.: Carbon electro-catalysis in the direct carbon fuel cell utilising alkali metal molten carbonates: a mechanistic review. J. Power Sources 453, 227662 (2020). https://doi.org/10.1016/j.jpowsour.2019.227662

55. Tanimoto, K., Yanagida, M., Kojima, T., Tamiya, Y., Matsumoto, H., Miyazaki, Y.: Long-term operation of small-sized single molten carbonate fuel cells. J. Power Sources 72(1), 77-82 (1998). https://doi.org/10.1016/S0378-7753(97)02673-6

56. Morita, H., Kawase, M., Mugikura, Y., Asano, K.: Degradation mechanism of molten carbonate fuel cell based on long-term performance: long-term operation by using bench-scale cell and post-test analysis of the cell. J. Power Sources 195(20), 6988-6996 (2010). https://doi.org/10.1016/j.jpowsour.2010. 04.084

57. Glugla, P., De Carlo, V.: The specific conductance of molten carbonate fuel cell tiles. J. Electrochem. Soc. 129(8), 1745 (1982). https://doi.org/10.1149/1.2124263

58. McKee, D.W., Spiro, C.L., Kosky, P.G., Lamby, E.J.: Catalysis of coal char gasification by alkali metal salts. Fuel 62(2), 217220 (1983). https://doi.org/10.1016/0016-2361(83)90202-8

59. McKee, D.W., Spiro, C.L., Kosky, P.G., Lamby, E.J.: Eutectic salt catalysts for graphite and coal char gasification. Fuel 64(6), 805-809 (1985). https://doi.org/10.1016/0016-2361(85) 90014-6

60. McKee, D.: Rare earth oxides as carbon oxidation catalysts. Carbon 23(6), 707-713 (1985). https://doi.org/10.1016/00086223(85)90232-5

61. Yu, X., Shi, Y., Wang, H., Cai, N., Li, C., Ghoniem, A.F.: Using potassium catalytic gasification to improve the performance of solid oxide direct carbon fuel cells: experimental characterization and elementary reaction modeling. J. Power Sources 252(2), 130-137 (2014). https://doi.org/10.1016/j.jpowsour.2013.12.021
62. Janz, G.J., Lorena, M.R.: Solid-liquid phase equilibria for mixtures of lithium, sodium, and potassium carbonates. J. Chem. Eng. Data 6(3), 321-323 (1961). https://doi.org/10.1021/je001 $03 \mathrm{a} 001$

63. Weaver, R., Leach, S., Nanis, L.: Electrolyte management for the coal air fuel cell. IECEC Conference (1981)

64. Kouchachvili, L., Ikura, M.: Performance of direct carbon fuel cell. Inter. J. Hydrogen Energy 36(16), 10263-10268 (2011). https://doi.org/10.1016/j.ijhydene.2010.10.036

65. Kojima, T., Yanagida, M., Tanimoto, K., Tamiya, Y., Matsumoto, H., MiyazakiI, Y.: The surface tension and the density of molten binary alkali carbonate systems. Electrochemistry 67(6), 593-602 (1999). https://doi.org/10.5796/electrochemistry.67.593

66. Posypaiko, V., Alekseeva, E., Vasina, N.: Diagrammy plavkosti solevykh sistem. Troynyye sistemy [Charts of salt systems' fusion. Triple systems]. Moscow: Chemistry (1977)

67. Licht, S.: Stabilization of STEP electrolyses in lithium-free molten carbonates. arXiv preprint arXiv:1209.3512. (2012)

68. Ang, P., Sammells, A.: Influence of electrolyte composition on electrode kinetics in the molten carbonate fuel cell. J. Electrochem. Soc. 127(6), 1287 (1980). https://doi.org/10.1149/198110. 0341PV

69. Belhomme, C., Devynck, J., Cassir, M.: New insight in the cyclic voltammetric behaviour of nickel in molten $\mathrm{Li}_{2} \mathrm{CO}_{3}-\mathrm{Na}_{2} \mathrm{CO}_{3}$ at $650{ }^{\circ} \mathrm{C}$. Electroanal. Chem. 545(27), 7-17 (2003). https://doi. org/10.1016/S0022-0728(03)00060-3

70. Maru, H.C., Dullea, J., Ong, E., Pigeaud, A., Sampath, V., Selman, J.R.: Fuel cell research on second-generation molten carbonate system. Institute of Gas Technology, Chicago (1976)

71. Morita, H., Komoda, M., Mugikura, Y., Izaki, Y., Watanabe, T., Masuda, Y., Matsuyama, T.: Performance analysis of molten carbonate fuel cell using a $\mathrm{Li} / \mathrm{Na}$ electrolyte. J. Power Sources 112(2), 509-518 (2002). https://doi.org/10.1016/S03787753(02)00468-8

72. Cantero-Tubilla, B., Xu, C., Zondlo, J.W., Sabolsky, K., Sabolsky, E.M.: Investigation of anode configurations and fuel mixtures on the performance of direct carbon fuel cells (DCFCs). J. Power Sources 238(2), 227-235 (2013). https://doi.org/10. 1016/j.jpowsour.2013.03.072

73. Mamantov, G., Mamantov, C.: Advances in molten salt chemistry 5. Elsevier Science Publishers Science and Technology Div (1983)

74. Vutetakis, D., Skidmore, D., Byker, H.: Electrochemical oxidation of molten carbonate-coal slurries. J. Electrochem. Soc. 134(12), 3027-3035 (1987). https://doi.org/10.1149/1.21003 34

75. Jiang, C., Ma, J., Arenillas, A., Irvinea, J.T.S.: Application of ternary carbonate in hybrid direct coal fuel cells. ECS Trans. 59(1), 281-288 (2014). https://doi.org/10.1149/05901.0281ecst

76. Eom, S., Cho, J., Ahn, S., Sung, Y., Choi, G., Kim, D.: Comparison of the electrochemical reaction parameter of graphite and sub-bituminous coal in a direct carbon fuel cell. Energ Fuel 30(4), 3502-3508 (2016). https://doi.org/10.1021/acs.energyfuels. 5 b02904

77. Li, C., Yi, H., Lee, D.: On-demand supply of slurry fuels to a porous anode of a direct carbon fuel cell: attempts to increase fuel-anode contact and realize long-term operation. J. Power Sources 309, 99-107 (2016). https://doi.org/10.1016/j.jpows our.2016.01.080

78. Lee, E.-K., Park, S.-A., Jung, H.-W., Kim, Y.-T.: Performance enhancement of molten carbonate-based direct carbon fuel cell (MC-DCFC) via adding mixed ionic-electronic conductors into Ni anode catalyst layer. J. Power Sources 386(15), 28-33 (2018). https://doi.org/10.1016/j.jpowsour.2017.03.078

79. Elleuch, A., Boussetta, A., Halouani, K., Li, Y.: Experimental investigation of direct carbon fuel cell fueled by almond shell 
biochar: Part II. Improvement of cell stability and performance by a three-layer planar configuration. Inter. J. Hydrogen Energy 38(36), 16605-16614 (2013). https://doi.org/10.1016/j.jhydene. 2013.07.061

80. Elleuch, A., Halouani, K., Li, Y.: Investigation of chemical and electrochemical reactions mechanisms in a direct carbon fuel cell using olive wood charcoal as sustainable fuel. J. Power Sources. 281(1), 350-361 (2015). https://doi.org/10.1016/j.jpowsour. 2015.01.171

81. Bian, W., Wu, W., Orme, C.J., Ding, H., Zhou, M., Ding, D.: Dual 3D ceramic textile electrodes: fast kinetics for carbon oxidation reaction and oxygen reduction reaction in direct carbon fuel cells at reduced temperatures. Adv. Funct. Mater. 30(19), 1-9 (2020). https://doi.org/10.1002/adfm.201910096

82. Hao, W., He, X., Mi, Y.: Achieving high performance in intermediate temperature direct carbon fuel cells with renewable carbon as a fuel source. Appl. Energy 135(15), 174-181 (2014). https:// doi.org/10.1016/j.apenergy.2014.08.055

83. Hao, W., Mi, Y.: A direct carbon fuel cell with a CuO-ZnO-SDC composite anode. RSC Adv. 6(55), 50201-50208 (2016). https:// doi.org/10.1039/c6ra04949d

84. He, W.: Adaptation of a one megawatt molten carbonate fuel cell system. Energy Convers. Manage. 38(7), 659-663 (1997). https:// doi.org/10.1016/S0196-8904(96)00080-5

85. Baur, E., Brunner, R.: Über die eisenoxyd-kathode in der kohleluft-kette. Zeitschrift für Elektrochemie und angewandte physikalische Chemie 43(9), 725-727 (1937). https://doi.org/10.1002/ bbpc. 19370430902

86. Anbar, M.: Methods and apparatus for the pollution-free generation of electrochemical energy. US Patent No 3,741,809 (1973)

87. Anbar, M., McMillen, D.F., Weaver, R.D., Jorgensen, P.J.: Method and apparatus for electrochemical generation of power from carbonaceous fuels. US Patent No 3,741,809 (1976)

88. McKee, D.W.: Gasification of graphite in carbon dioxide and water vapor-the catalytic effects of alkali metal salts. Carbon 20(1), 59-66 (1982). https://doi.org/10.1016/0008-6223(82) 90075-6

89. Dunks, G.B.: Electrochemical studies of graphite oxidation in sodium carbonate melt. Inorg. Chem. 23(7), 828-837 (1984). https://doi.org/10.1021/ic00175a008

90. Cooper, J.F., Krueger, R., Cherepy, N.: Fuel cell apparatus and method thereof. US Patent No 6815105B2 (2004)

91. Luo, Z., Wang, S., Liao, Y., Zhou, J., Gu, Y., Cen, K.: Research on biomass fast pyrolysis for liquid fuel. Biomass Bioenergy 26(5), 455-462 (2004). https://doi.org/10.1016/j.biombioe. 2003.04.001

92. Huang, J., Mao, Z., Yang, L., Peng, R.: SDC-Carbonate composite electrolytes for low-temperature SOFCs. Electrochem. Solid State 8(9), A437-A440 (2005). https://doi.org/10.1149/1. 1960139

93. Cooper, J.F., Cherepy, N., Krueger, R.L.: Tilted fuel cell apparatus. US Patent No 6878479B2 (2005)

94. Cooper, J.F.: Reactions of the carbon anode in molten carbonate electrolyte. Presentations in Direct Carbon Fuel Cell Workshop, NETL (2003)

95. Cooper, J.F.: Direct conversion of coal and coal-derived carbon in fuel cells. The 2nd International Conference on Fuel Cell Science, Engineering and Technology (2004)

96. Li, X., Zhu, Z.H., Roland, D.M., Andrew, D., John, B., Liu, S., Lu, G.Q.: Factors that determine the performance of carbon fuels in the direct carbon fuel cell. Ind. Eng. Chem. Res. 47(23), 9670-9677 (2008). https://doi.org/10.1021/ie800891m

97. Li, X., Zhu, Z., Roland, D.M., John, B., Andrew, D.: Modification of coal as a fuel for the direct carbon fuel cell. J. Phys. Chem. A 114(11), 3855-3862 (2010). https://doi.org/10.1021/ jp9062719
98. Zhang, J., Zhong, Z., Shen, D., Xiao, J., Fu, Z., Zhang, H., Zhao, J., Li, W., Yang, M.: Characteristics of a fluidized bed electrode for a direct carbon fuel cell anode. J. Power Sources 196(6), 3054-3059 (2011). https://doi.org/10.1016/j.jpowsour.2010.11. 130

99. Ido, A., Kawase, M.: Development of a tubular molten carbonate direct carbon fuel cell and basic cell performance. J. Power Sources 449(15), 227483 (2020). https://doi.org/10.1016/j.jpows our.2019.227483

100. Gür, T.M., Huggins, R.A.: Direct electrochemical conversion of carbon to electrical energy in a high temperature fuel cell. J. Electrochem. Soc. 139(10), L95 (1992). https://doi.org/10. $1149 / 1.2069025$

101. Zhang, J., Jiang, X., Piao, G., Yang, H., Zhong, Z.: Simulation of a fluidized bed electrode direct carbon fuel cell. Inter. J. Hydrogen Energy 40(8), 3321-3331 (2015). https://doi.org/10.1016/j. ijhydene.2014.12.090

102. Kruesi, W., Fray, D.: Fundamental study of the anodic and cathodic reactions during the electrolysis of a lithium carbonatelithium chloride melt using a carbon anode. J. Appl. Electrochem. 24(11), 1102-1108 (1994). https://doi.org/10.1007/BF002 41307

103. Weaver, R.D., Nanis, L.: Electrochemical oxidation of carbon in a molten carbonate coal-air fuel cell. J. Electrochem. Soc. 1981, 316-333 (1981). https://doi.org/10.1149/198109.0316PV

104. Glenn, M.J., Allen, J.A., Donne, S.W.: Carbon gasification from a molten carbonate eutectic. Energy Technol-ger. (2019). https:// doi.org/10.1002/ente.201900602

105. Watanabe, H., Umehara, D., Hanamura, K.: Impact of gas products around the anode on the performance of a direct carbon fuel cell using a carbon/carbonate slurry. J. Power Sources 329, 567-573 (2016). https://doi.org/10.1016/j.jpowsour.2016.08.122

106. Kaklidis, N., Strandbakke, R., Arenillas, A., Menéndez, J.A., Konsolakis, M., Marnellos, G.E.: The synergistic catalyst-carbonates effect on the direct bituminous coal fuel cell performance. Inter. J. Hydrogen Energy 44(20), 10033-10042 (2019). https://doi.org/10.1016/j.ijhydene.2019.02.038

107. Tamaru, S., Kamada, M.: Brennstoffketten, deren Arbeitstemperatur unterhalb $600{ }^{\circ} \mathrm{C}$ liegt. Zeitschrift für Elektrochemie und angewandte physikalische Chemie 41(2), 93-96 (1935). https:// doi.org/10.1002/bbpc. 19350410207

108. Thonstad, J.: The electrode reaction on the $\mathrm{C}, \mathrm{CO}_{2}$ electrode in cryolite-alumina melts-I Steady state measurements. Electrochim. Acta. 15(10), 1569-1580 (1970). https://doi.org/10.1016/ 0013-4686(70)80079-2

109. Lee, E.-K., Chun, H.H., Kim, Y.-T.: Enhancing Ni anode performance via $\mathrm{Gd} 2 \mathrm{O} 3$ addition in molten carbonate-type direct carbon fuel cell. Inter. J. Hydrogen Energy 39(29), 16541-16547 (2014). https://doi.org/10.1016/j.ijhydene.2014.03.180

110. Bie, K., Fu, P., Liu, Y., Muhammad, A.: Comparative study on the performance of different carbon fuels in a molten carbonate direct carbon fuel cell with a novel anode structure. J. Power Sources (2020). https://doi.org/10.1016/j.jpowsour.2020.228101

111. Eguchi, K., Setoguchi, T., Inoue, T., Arai, H.: Electrical properties of ceria-based oxides and their application to solid oxide fuel cells. Solid State Ion. 52(1-3), 165-172 (1992). https://doi.org/ 10.1016/0167-2738(92)90102-U

112. Zhu, B.: Functional ceria-salt-composite materials for advanced ITSOFC applications. J. Power Sources 114(1), 1-9 (2003). https://doi.org/10.1016/s0378-7753(02)00592-X

113. Elleuch, A., Yu, J., Boussetta, A., Halouani, K., Li, Y.: Electrochemical oxidation of graphite in an intermediate temperature direct carbon fuel cell based on two-phases electrolyte. Inter. J. Hydrogen Energy 38(20), 8514-8523 (2013). https://doi.org/10. 1016/j.ijhydene.2012.11.070 
114. Li, Y., Rui, Z., Xia, C., Anderson, M., Lin, Y.S.: Performance of ionic-conducting ceramic/carbonate composite material as solid oxide fuel cell electrolyte and $\mathrm{CO}_{2}$ permeation membrane. Catal Today 148(3-4), 303-309 (2009). https://doi.org/10.1016/j.cattod.2009.08.009

115. Rui, Z., Anderson, M., Lin, Y.S., Li, Y.: Modeling and analysis of carbon dioxide permeation through ceramic-carbonate dualphase membranes. J. Membr. Sci. 345(1-2), 110-118 (2009). https://doi.org/10.1016/j.memsci.2009.08.034

116. Lahijani, P., Zainal, Z.A., Mohammadi, M., Mohamed, A.R.: Conversion of the greenhouse gas $\mathrm{CO}_{2}$ to the fuel gas $\mathrm{CO}$ via the boudouard reaction: a review. Renew. Sust. Energy Rev. 41, 615-632 (2015). https://doi.org/10.1016/j.rser.2014.08.034

117. Jia, L., Tian, Y., Liu, Q., Xia, C., Yu, J., Wang, Z., Zhao, Y., Li, Y.: A direct carbon fuel cell with (molten carbonate)/(doped ceria) composite electrolyte. J. Power Sources 195(17), 55815586 (2010). https://doi.org/10.1016/j.jpowsour.2010.03.016

118. Wu, W., Zhang, Y., Ding, D., He, T.: A high-performing direct carbon fuel cell with a 3D architectured anode operated below $600^{\circ} \mathrm{C}$. Adv. Mater. 30(4), 1704745 (2018). https://doi.org/10. 1002/adma. 201704745

119. Nabae, Y., Pointon, K.D., Irvine, J.T.S.: Ni/C slurries based on molten carbonates as a fuel for hybrid direct carbon fuel cells. J. Electrochem. Soc. 156(6), B716-B720 (2009). https://doi.org/ 10.1149/1.3110862

120. Alexander Lipilin, Iouri Balachov, Lawrence Dubois, Angel Sanjurjo, Michael McKubre, Steven Crouch-Baker, Marc Hornbostel, Tanzella, F.: Liquid anode electrochemical cell. US Patent No 2007/0269688 A1 (2007)

121. Jain, S.L., Barry Lakeman, J., Pointon, K.D., Marshall, R., Irvine, J.T.S.: Electrochemical performance of a hybrid direct carbon fuel cell powered by pyrolysed MDF. Energy Environ. Sci. 2(6), 687-693 (2009). https://doi.org/10.1039/b820836k

122. Jiang, C., Irvine, J.T.S.: Catalysis and oxidation of carbon in a hybrid direct carbon fuel cell. J. Power Sources 196(17), 7318-7322 (2011). https://doi.org/10.1016/j.jpowsour.2010. 11.066

123. Ruflin, J., Perwich, A.D., II., Brett, C., Berner, J.K., Lux, S.M.: Direct carbon fuel cell: a proposed hybrid design to improve commercialization potential. J. Power Sources 213, 275-286 (2012). https://doi.org/10.1016/j.jpowsour.2012.04.048

124. Deleebeeck, L., Hansen, K.K.: HDCFC performance as a function of anode atmosphere $\left(\mathrm{N}_{2}-\mathrm{CO}_{2}\right)$. J. Electrochem. Soc. 161(1), F33-F46 (2013). https://doi.org/10.1149/2.027401jes

125. Deleebeeck, L., Ippolito, D., Hansen, K.K.: Enhancing hybrid direct carbon fuel cell anode performance using $\mathrm{Ag}_{2} \mathrm{O}$. Electrochim. Acta. 152, 222-239 (2015). https://doi.org/10.1016/j. electacta.2014.11.064

126. Pointon, K., Lakeman, B., Irvine, J., Bradley, J., Jain, S.: The development of a carbon-air semi fuel cell. J. Power Sources 162(2), 750-756 (2006). https://doi.org/10.1016/j.jpowsour. 2005.07 .023

127. Jain, S., Lakeman, B., Pointon, K.D., Irvine, J.T.: Carbon content in a direct carbon fuel cell. Ecs. Trans. 7(1), 829-836 (2007). https://doi.org/10.1149/1.2729172

128. Jain, S.L., Nabae, Y., Lakeman, B.J., Pointon, K.D., Irvine, J.T.S.: Solid state electrochemistry of direct carbon/air fuel cells. Solid State Ion. 179(27-32), 1417-1421 (2008). https:// doi.org/10.1016/j.ssi.2008.01.078

129. Lee, A.C., Mitchell, R.E., Gür, T.M.: Thermodynamic analysis of gasification-driven direct carbon fuel cells. J. Power Sources 194(2), 774-785 (2009). https://doi.org/10.1016/j.jpowsour. 2009.05.039

130. Lee, A.C., Mitchell, R.E., Gür, T.M.: Modeling of CO2gasification of carbon for integration with solid oxide fuel cells.
AIChE J. 55(4), 983-992 (2009). https://doi.org/10.1002/aic. 11713

131. White, S., Twardoch, U.: The solubility and electrochemistry of alkali metal oxides in the molten eutectic mixture of lithium carbonate-sodium carbonate-potassium carbonate. J. Appl. Electrochem. 19(6), 901-910 (1989). https://doi.org/10.1007/BF010 07939

132. Peeters, D., Moyaux, D., Claes, P.: (1999) Solubility and solvation of carbon dioxide in the molten $\mathrm{Li} 2 \mathrm{CO} 3 / \mathrm{Na} 2 \mathrm{CO} 3 / \mathrm{K} 2 \mathrm{CO} 3$ (43.5: $31.5: 25.0 \mathrm{~mol} \%$ ) eutectic mixture at $973 \mathrm{~K}$ II. Theoretical Part. Eur. J. Inorg. Chem. 4, 589-592 (1999). https://doi.org/10. 1002/(SICI)1099-0682(199904)1999:4

133. Nakagawa, N., Ishida, M.: Performance of an internal directoxidation carbon fuel cell and its evaluation by graphic exergy analysis. Ind. Eng. Chem. Res. 27(7), 1181-1185 (1988). https:// doi.org/10.1021/ie00079a016

134. Hemmes, K., Cassir, M.: A theoretical study of the carbon/carbonate/hydroxide (electro-) chemical system in a direct carbon fuel cell. J. Fuel Cell Sci. Technol. 8(5), 1 (2011). https://doi.org/ 10.1115/1.4003750

135. Li, S., Pan, W., Wang, S., Meng, X., Jiang, C., Irvine, J.T.: Electrochemical performance of different carbon fuels on a hybrid direct carbon fuel cell. Inter. J. Hydrogen Energy 42(25), 1627916287 (2017). https://doi.org/10.1016/j.ijhydene.2017.05.150

136. Lee, J.Y., Song, R.H., Lee, S.B., Lim, T.H., Park, S.J., Shul, Y.G., Lee, J.W.: A performance study of hybrid direct carbon fuel cells: Impact of anode microstructure. Inter. J. Hydrogen Energy 39(22), 11749-11755 (2014). https://doi.org/10.1016/j.ijhydene. 2014.05.145

137. Ma, J., Zhang, B., Hou, X., Gong, J., Yu, H., Xu, R., Jiang, C.: The function of carbonate in a hybrid direct carbon fuel cell. Solid State Ion. 344, 115094-115099 (2020). https://doi.org/ 10.1016/j.ssi.2019.115094

138. McKee, D., Chatterji, D.: The catalytic behavior of alkali metal carbonates and oxides in graphite oxidation reactions. Carbon 13(5), 381-390 (1975). https://doi.org/10.1016/0008-6223(75) 90006-8

139. McKee, D.W.: Mechanisms of the alkali metal catalysed gasification of carbon. Fuel 62(2), 170-175 (1983). https://doi.org/10. 1016/0016-2361(83)90192-8

140. McKee, D., Chatterji, D.: The catalyzed reaction of graphite with water vapor. Carbon 16(1), 53-57 (1978). https://doi.org/ 10.1016/0008-6223(78)90116-1

141. Nagase, K., Shimodaira, T., Itoh, M., Zheng, Y.: Kinetics and mechanisms of the reverse Boudouard reaction over metal carbonates in connection with the reactions of solid carbon with the metal carbonates. Phys. Chem. Chem. Phys. 1(24), 5659-5664 (1999). https://doi.org/10.1039/A906687J

142. Selman, J.R.: Molten-salt fuel cells-technical and economic challenges. J. Power Sources 160(2), 852-857 (2006). https:// doi.org/10.1016/j.jpowsour.2006.04.126

143. Kulkarni, A., Giddey, S.: Materials issues and recent developments in molten carbonate fuel cells. J. Solid State Electr. 16(10), 3123-3146 (2012). https://doi.org/10.1007/s10008-012-1771-y

144. Kudo, T., Hisamitsu, Y., Kihara, K., Mohamedi, M., Uchida, I.: X-ray diffractometric study of in situ oxidation of $\mathrm{Ni}$ in $\mathrm{Li} / \mathrm{K}$ and $\mathrm{Li} / \mathrm{Na}$ carbonate eutectic. J. Power Sources 104(2), 272-280 (2002). https://doi.org/10.1016/S0378-7753(01)00962-4

145. Doyon, J.D., Gilbert, T., Davies, G., Paetsch, L.: NiO solubility in mixed alkali/alkaline earth carbonates. J. Electrochem. Soc. 134(12), 3035 (1987). https://doi.org/10.1149/1.2100335

146. Scaccia, S.: Investigation on $\mathrm{NiO}$ solubility in binary and ternary molten alkali metal carbonates containing additives. J. Mol. Liq. 116(2), 67-71 (2005). https://doi.org/10.1016/j.molliq.2004.07. 078 
147. Huang, B., Li, F., Yu, Q.-C., Chen, G., Zhao, B.-Y., Hu, K.-A.: Study of NiO cathode modified by $\mathrm{ZnO}$ additive for MCFC. J. Power Sources 128(2), 135-144 (2004). https://doi.org/10. 1016/j.jpowsour.2003.10.008

148. Kim, S.-G., Yoon, S.P., Han, J., Nam, S.W., Lim, T.H., Oh, I.-H., Hong, S.-A.: A study on the chemical stability and electrode performance of modified $\mathrm{NiO}$ cathodes for molten carbonate fuel cells. Electrochim. Acta. 49(19), 3081-3089 (2004). https://doi. org/10.1016/j.electacta.2004.01.027

149. Tanimoto, K., Kojima, T., Yanagida, M., Nomura, K., Miyazaki, Y.: Optimization of the electrolyte composition in a ( $\mathrm{Li} 0.52 \mathrm{Na} 0.48) 2-2 x \mathrm{AExCO} 3(\mathrm{AE}=\mathrm{Ca}$ and $\mathrm{Ba}$ ) molten carbonate fuel cell. J. Power Sources 131(12), 256-260 (2004). https://doi. org/10.1016/j.jpowsour.2003.11.085

150. Soler, J., Gonzalez, T., Escudero, M., Rodrigo, T., Daza, L.: Endurance test on a single cell of a novel cathode material for MCFC. J. Power Sources 106(1-2), 189-195 (2002). https://doi. org/10.1016/S0378-7753(01)01041-2

151. Matsuzawa, K., Mizusaki, T., Mitsushima, S., Kamiya, N., Ota, K.-I.: The effect of La oxide additive on the solubility of $\mathrm{NiO}$ in molten carbonates. J. Power Sources 140(2), 258-263 (2005). https://doi.org/10.1016/j.jpowsour.2004.08.041

152. Daza, L., Rangel, C., Baranda, J., Casais, M., Martınez, M., Alonso, J.: Modified nickel oxides as cathode materials for MCFC. J. Power Sources 86(1-2), 329-333 (2000). https://doi. org/10.1016/S0378-7753(99)00499-1

153. Ota, K.-I., Matsuda, Y., Matsuzawa, K., Mitsushima, S., Kamiya, N.: Effect of rare earth oxides for improvement of MCFC. J. Power Sources 160(2), 811-815 (2006). https://doi. org/10.1016/j.jpowsour.2006.04.055

154. Liu, Z., Guo, P., Zeng, C.: Effect of Dy on the corrosion of $\mathrm{NiO} / \mathrm{Ni}$ in molten $(0.62 \mathrm{Li}, 0.38 \mathrm{~K}) 2 \mathrm{CO} 3$. J. Power Sources 166(2), 348-353 (2007). https://doi.org/10.1016/j.jpowsour. 2007.01.063

155. Suski, L., Kołacz, J., Mordarski, G., Ruggiero, M.: Determination of open-circuit potentials at gas/electrode/YSZ boundary versus molten carbonate reference electrode at medium temperatures. Electrochim. Acta. 50(14), 2771-2780 (2005). https://doi.org/10.1016/j.electacta.2004.11.023

156. Lee, J.-A., Lee, H.-C., Heo, Y.-W., Lee, J.-H., Kim, J.-J.: Effect of Li doping on sintering characteristics and microstructural behavior of yttria-stabilized zirconia. Ceram. Int. 42(15), 17339-17346 (2016). https://doi.org/10.1016/j.ceramint.2016. 08.030

157. Kohli, R.: The thermodynamic properties of alkali metal compounds at high temperatures. J. Therm. Anal. Calorim. 41(6), 1571-1576 (1994). https://doi.org/10.1007/BF02549955

158. Chandrakala, H.N., Ramaraj, B.: Shivakumaraiah, siddaramaiah: influence of lithium potassium zirconate nanoparticles on the electrical properties and structural characteristics of poly(vinyl alcohol) films. J. Phys. Chem. Solids 75(2), 252-258 (2014). https://doi.org/10.1016/j.jpcs.2013.09.025

159. Pasierb, P., Gajerski, R., Komornicki, S., RÄkas, M.: Reactivity of lithium and barium carbonates with $\mathrm{ZrO}_{2}: \mathrm{Y}_{2} \mathrm{O}_{3}$ and Nasicon in solid state electrochemical gas sensors. J. Therm. Anal. Calorim. 77, 105-113 (2004). https://doi.org/10.1023/B:JTAN.00000 33193.98853.d0

160. Wade, J.L., Lee, C., West, A.C., Lackner, K.S.: Composite electrolyte membranes for high temperature $\mathrm{CO}_{2}$ separation. J. Membr. Sci. 369(1-2), 20-29 (2011). https://doi.org/10.1016/j. memsci.2010.10.05

161. Xu, X., Zhou, W., Zhu, Z.: Stability of YSZ and SDC in molten carbonate eutectics for hybrid direct carbon fuel cells. RSC Adv. 4(5), 2398-2403 (2014). https://doi.org/10.1039/c3ra46600k

162. Badwal, S., Ciacchi, F.T., Drennan, J.: Investigation of the stability of ceria-gadolinia electrolytes in solid oxide fuel cell environments. Solid State Ion. 121(1-4), 253-262 (1999). https:// doi.org/10.1016/S0167-2738(99)00044-2

163. Guo, L.Q., Zhao, X.M., Wang, B.C., Bai, Y., Xu, B.Z., Qiao, L.J.: The initial stage of atmospheric corrosion on interstitial free steel investigated by in situ SPM. Corros. Sci. 70, 188-193 (2013). https://doi.org/10.1016/j.corsci.2013.01.028

164. Jiao, Y., Tian, W., Chen, H., Shi, H., Yang, B., Li, C., Shao, Z., Zhu, Z., Li, S.-D.: In situ catalyzed boudouard reaction of coal char for solid oxide-based carbon fuel cells with improved performance. Appl. Energy 141, 200-208 (2015). https://doi.org/10. 1016/j.apenergy.2014.12.048

165. Ali, A., Shehzad Bashir, F., Raza, R., Rafique, A., Kaleem Ullah, M., Alvi, F., Afzal, M., Ghauri, M., Belova, L.M.: Electrochemical study of composite materials for coal-based direct carbon fuel cell. Inter. J. Hydrogen Energy 43(28), 12900-12908 (2018). https://doi.org/10.1016/j.ijhydene.2018.05.104

166. Jiang, C., Ma, J., Ana, A., John, T.S.I.: Hybrid direct carbon fuel cells with different types of mineral coal. ECS Trans. 57(1), 3013-3021 (2013). https://doi.org/10.1149/05701.3013ecst

167. Jiang, C., Ma, J., Arenillas, A., Irvine, J.T.: Application of ternary carbonate in hybrid direct coal fuel cells. ECS Trans. 59(1), 281-288 (2014). https://doi.org/10.1149/05901.0281ecst

168. Chien, A.C., Arenillas, A., Jiang, C., Irvine, J.T.S.: Performance of direct carbon fuel cells operated on coal and effect of operation mode. J. Electrochem. Soc. 161(5), F588-F593 (2014). https://doi.org/10.1149/2.025405jes

169. Ju, H., Eom, J., Lee, J.K., Choi, H., Lim, T.-H., Song, R.-H., Lee, J.: Durable power performance of a direct ash-free coal fuel cell. Electrochim. Acta. 115, 511-517 (2014). https://doi. org/10.1016/j.electacta.2013.10.124

170. Devyatkin, S.V., Pisanenko, A.D., Shapoval, V.I.: Chemical and electrochemical behavior of carbonate melts containing silicon oxide. Russ. J. Appl. Chem. 75(4), 562-564 (2002). https://doi.org/10.1023/A:101950482

171. Tulloch, J., Allen, J., Wibberley, L., Donne, S.: Influence of selected coal contaminants on graphitic carbon electro-oxidation for application to the direct carbon fuel cell. J. Power Sources 260(15), 140-149 (2014). https://doi.org/10.1016/j. jpowsour.2014.03.026

172. Eom, S., Ahn, S., Kang, K., Choi, G.: Correlations between electrochemical resistances and surface properties of acidtreated fuel in coal fuel cells. Energy 140(2), 885-892 (2017). https://doi.org/10.1016/j.energy.2017.09.034

173. Eom, S., Ahn, S., Choi, G.: Effect of fuel acid treatment on the reduction of electrochemical resistance in a direct carbon fuel cell system. Energy Fuel 35(5), 4493-4501 (2021). https://doi. org/10.1021/acs.energyfuels.0c03714

174. Xie, H., Zhai, S., Chen, B., Liu, T., Zhang, Y., Ni, M., Shao, Z.: Coal pretreatment and Ag-infiltrated anode for high-performance hybrid direct coal fuel cell. Appl. Energy (2020). https://doi.org/10.1016/j.apenergy.2019.114197

175. Dudek, M.: On the utilization of coal samples in direct carbon solid oxide fuel cell technology. Solid State Ion. 271(2), 121-127 (2015). https://doi.org/10.1016/j.ssi.2014.09.034

176. Kim, J.-W., Lee, Y.-D., Lee, H.-G.: Decomposition of $\mathrm{Li}_{2} \mathrm{CO}_{3}$ by interaction with $\mathrm{SiO}_{2}$ in mold flux of steel continuous casting. ISIJ Int. 44(2), 334-341 (2004). https://doi.org/10.2355/isijintern ational.44.334

177. Li, C., Yi, H., Eom, S., Choi, G., Choi, T.-Y., Lee, D.: Intrinsic solid-state reaction characteristics of coals and chars in a direct carbon fuel cell: with focus on significance assessment of fuelborne factors. Energy Fuel 34(4), 4129-4138 (2020). https://doi. org/10.1021/acs.energyfuels.9b04387

178. Cai, W., Liu, J., Liu, P., Liu, Z., Xu, H., Chen, B., Li, Y., Zhou, Q., Liu, M., Ni, M.: A direct carbon solid oxide fuel cell fueled

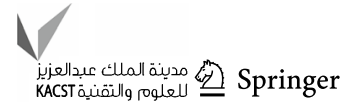


with char from wheat straw. Inter. J. Hydrogen Energy 43(7), 2468-2477 (2018). https://doi.org/10.1002/er.3968

179. Xu, L.J., Liu, S.A., Wang, Z.Z., Liu, C.Y., Li, S.G.: Zinc isotopic compositions of migmatites and granitoids from the Dabie Orogen, central China: Implications for zinc isotopic fractionation during differentiation of the continental crust. Lithos 324, 454-465 (2019). https://doi.org/10.1016/j.lithos.2018.11.028

180. Peng, F., Li, Y., Nash, P., Cooper, J.F., Parulekar, S.J., Selman, J.R.: Direct carbon fuel cells-wetting behavior of graphitic carbon in molten carbonate. Inter. J. Hydrogen Energy 41(41), 18858-18871 (2016). https://doi.org/10.1016/j.matchemphys. 2006.06.006

181. Chen, M., Wang, C., Niu, X., Zhao, S., Tang, J., Zhu, B.: Carbon anode in direct carbon fuel cell. Inter. J. Hydrogen Energy 35(7), 2732-2736 (2010). https://doi.org/10.1016/j.ijhydene.2009.04. 051

182. Hong, S.-G., Selman, J.R.: Wetting characteristics of carbonate melts under MCFC operating conditions. J. Electrochem. Soc. 151(1), A77-A84 (2004). https://doi.org/10.1149/1.1629094

183. Cao, D., Wang, G., Wang, C., Wang, J., Lu, T.: Enhancement of electrooxidation activity of activated carbon for direct carbon fuel cell. Inter. J. Hydrogen Energy 35(4), 1778-1782 (2010). https://doi.org/10.1016/j.ijhydene.2009.12.133
184. Watanabe, H., Kimura, A., Okazaki, K.: Impact of ternary carbonate composition on the morphology of the carbon/carbonate slurry and continuous power generation by direct carbon fuel cells. Energy Fuel 30(3), 1835-1840 (2016). https://doi.org/10. 1021/acs.energyfuels.5b02224

185. Ahn, S.Y., Eom, S.Y., Rhie, Y.H., Sung, Y.M., Moon, C.E., Choi, G.M., Kim, D.J.: Application of refuse fuels in a direct carbon fuel cell system. Energy 51(1), 447-456 (2013). https://doi.org/ 10.1016/j.energy.2012.12.025

186. Gür, T.M.: Solid fuel utilization in high temperature fuel cells. ECS Trans. 41(12), 29-38 (2019). https://doi.org/10.1149/1. 3697426

187. Jayakumar, A., Küngas, R., Roy, S., Javadekar, A., Buttrey, D.J., Vohs, J.M., Gorte, R.J.: A direct carbon fuel cell with a molten antimony anode. Energy Environ. Sci. (2011). https://doi.org/10. 1039/c1ee01863a

Publisher's Note Springer Nature remains neutral with regard to jurisdictional claims in published maps and institutional affiliations. 